\title{
Research Paper \\ Planning and Evaluating the Effectiveness of Behavioral Intervention on Reducing Physical Bullying and Improving School Bonding in Students: A School-Based Perspective
}

\section{Mina Mohebbi ${ }^{1}$, Mirmahmoud Mirnasab ${ }^{2}$, Eskandar Fathiazar ${ }^{* 3}$, Touraj Hashemi ${ }^{4}$}

1. Ph.D.in Educational Psychology, Faculty of Education \& Psychology, University of Tabriz, Iran 2. Associate Professor, Department of Education, Faculty of Education \& Psychology, University of Tabriz, Iran

3. Professor, Department of Education, Faculty of Education \& Psychology, University of Tabriz, Iran

4. Professor, Department of Psychology, Faculty of Education \& Psychology, University of Tabriz, Iran

Citation: Mohebbi M, Mirnasab M, Fathiazar E, Hashemi T. Planning and evaluating the effectiveness of behavioral intervention on reducing physical bullying and improving school bonding in students: a school-based perspective. Quarterly Journal of Child Mental Health. 2019; 6(3): $1-14$.

\section{http://dx.doi.org/10.29252/jcmh.6.3.2}

\section{A R T I C L E I N F O}

\section{Keywords:}

School bonding, bullying, school-based behavioral intervention

Received: 4 Apr 2018 Accepted: 3 Sep 2018 Available: 9 Nov 2019

\section{A B S T R A C T}

Background and Purpose: School bullying has been regarded as a serious concern in schools worldwide. Thus, it is critical for researchers and psychologists to use effective intervention strategies to manage bullying behaviors in the schools. Bullying intervention requires taking a school-based approach in which bullies, peers, and teachers are engaged. The present study aimed to plan and evaluate the effectiveness of school-based behavioral intervention on students bullying behavior and school bonding.

Method: This study was a quasi-experimental research with pretest-posttest control group design. The participants were 30 bully students, 15 pro-bully students, and four fifth-grade teachers of governmental primary schools in Tabriz city in the academic year 2016-2017. They were selected by purposeful sampling, one-stage cluster sampling, and screening procedures. Measurement instruments included the Peer Nomination Form (Pekarik et al., 1976), Teacher Nomination Form (Werthamer-Larsson et al., 1991), Pro-bully Nomination Form (Salmivalli et al., 1996), Illinois Bullying Scale (Espelage \& Holt, 2001), and School Bonding Scale (Cernkovich \& Giordano, 1992). In addition 8 one-hour sessions of school-based behavioral intervention was conducted for 8 week. Multivariate analysis of covariance (MANCOVA) was used to analyze the data .

Results: The results revealed that school-based behavioral intervention can reduce bullying and fighting and improve teacher and school attachment and school involvement among bully students ( $>0.001, \mathrm{~F}=9.78$ ).

Conclusion: The results indicate that school-based behavioral intervention through the behavior management training to bullies, teachers and pro-bullies is effective in reducing components of bullying behavior and improving components of school bonding and can be used as an appropriate intervention procedure for children with physical bullying behavior. In addition, the results of this study can help the school counselors, education psychologists, and teachers to improve children school bonding.

\footnotetext{
* Corresponding author: Eskandar Fathiazar, Professor, Department of Education, Faculty of Education \& Psychology, University of Tabriz, Iran.
}

E-mail addresses: E-fathiazar@Tabrizu.ac.ir 


\title{
طرواحى و ارزيابى اثربخشى مداخله رفتارى بر كاهش قلدرى جسمانى و بهبود ييوند با مدرسه در دانش آموزان: روى آورد مدرسه محتور
}

\author{
مينا محبى '، مير محمود ميرنسب'، اسكندر فتحى آذر "، تورج هاشمى

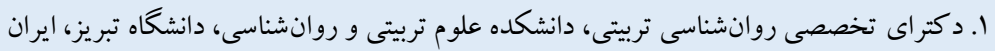

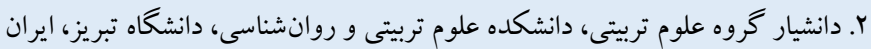

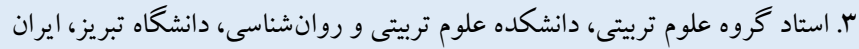

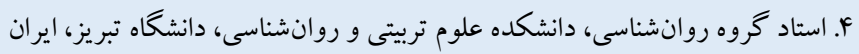

\section{جكيده}

زمينه و هدف: قلدرى مدرسهمحور در مدارس سراسر دنيا بهعنوان يكك نخرانى جدى مطرح شده است؛ بنابراين استفاده از راهبردهاى

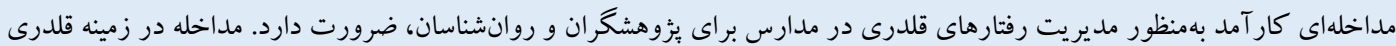

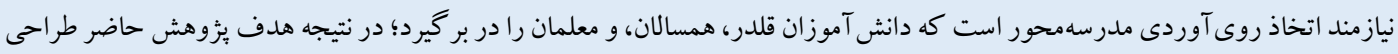

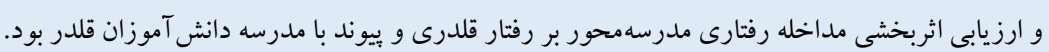

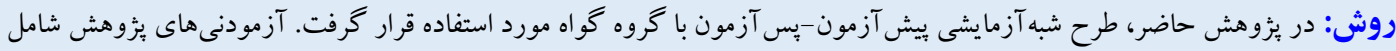

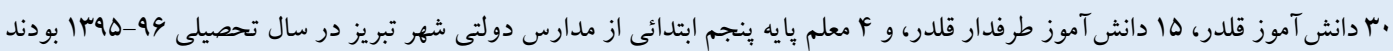

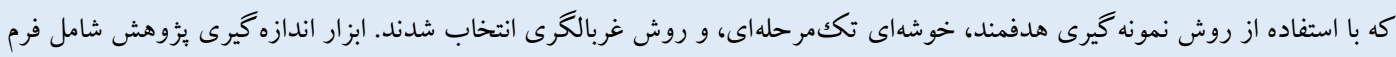

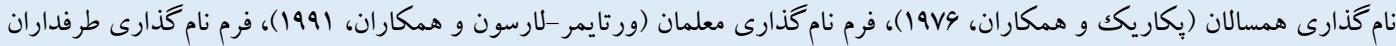

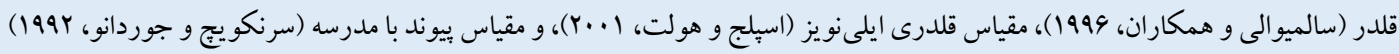

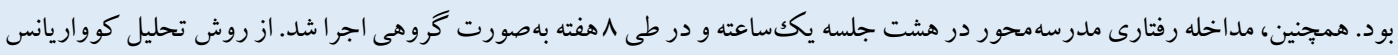
تجندمتغيرى براى تجزيهو تحليل دادههاى يُزوهش استفاده شد.

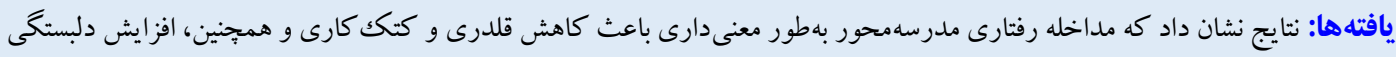

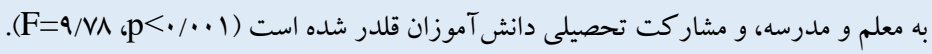

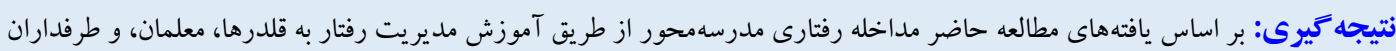

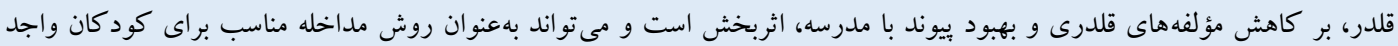

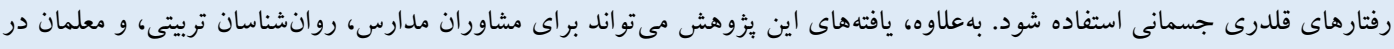
بهبود ييوند با مدرسه كود كان، كمكك كنده باشد.
مشخصات مقاله

كليدوازهها:

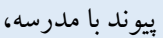
قلدرى، مداخله رفتارى مدرسه-محور

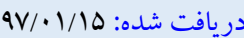

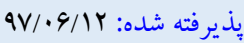

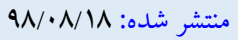

* نويسنده مسئول: اسكندر فتحى آذر، استاد گروه علوم ترييى، دانشكده علوم تربيتى و روانشناسى، دانشكاه تبريز، ايران.

E-fathiazar@Tabrizu.ac.ir

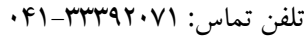


شــن ناكار آمد ايجاد شـده و بعدها زمينهسـاز رفتارهاى انحر افى مىشود

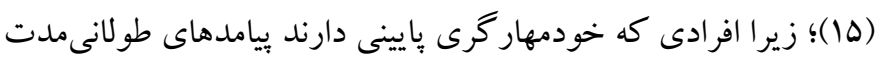

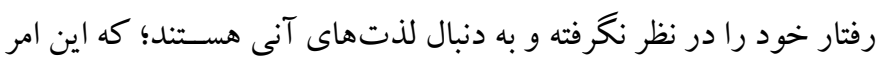

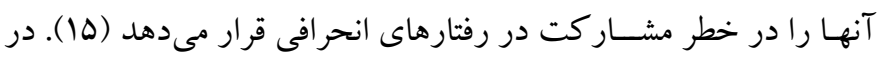

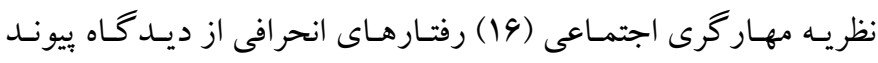

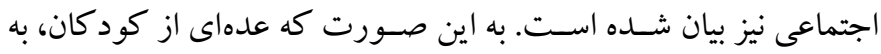

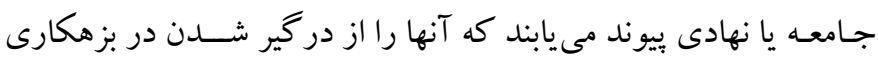

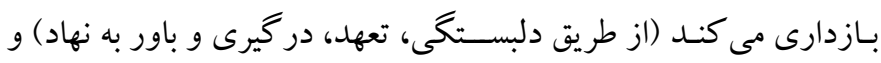

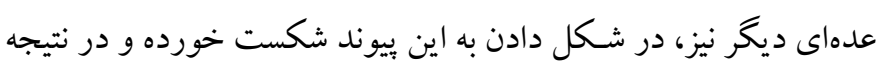

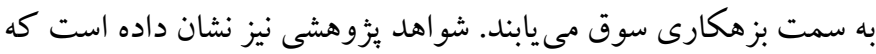

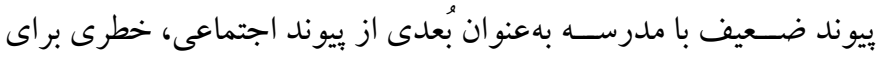

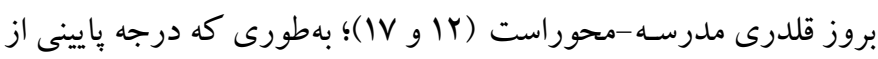

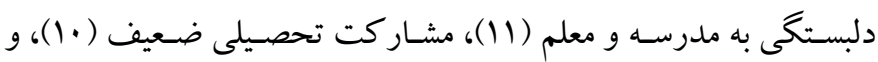

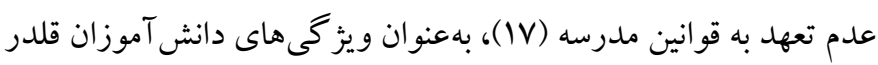
مطرح شده است. با توجه به بيامدهاى منفى يديده قلدرى بر افراد قلدر و جوّ مدرسـهه،

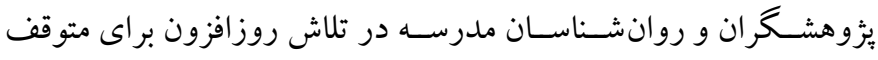

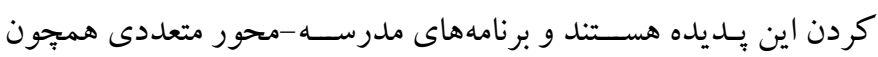

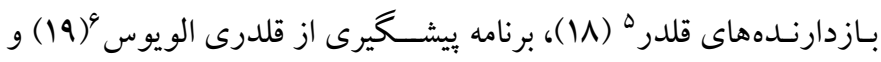

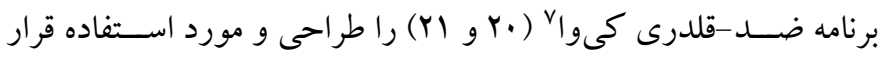
دادهاند. بهعلاوه، مداخله رفتارى^از جمله مداخلاتى اسـت كه هم قابليت

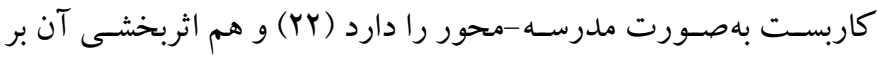

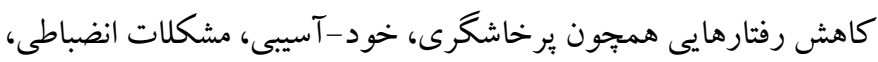

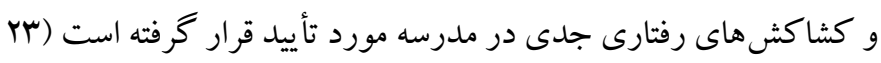

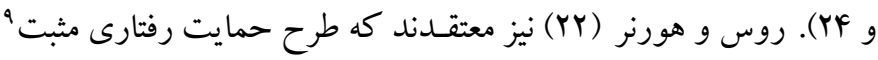

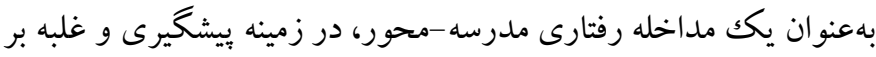
رفتار قلدرى، روشى كار آمد است.

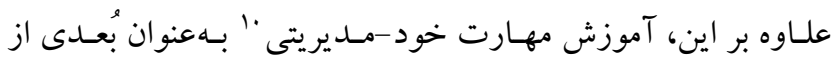
مــداخلات رفتارى روى افراد واجد رفتارهاى مبارزهطلبانه اجرا مى شـــود

6. Olweus bullying prevention program

7. KiVa anti-bullying program

8. Behavioral intervention

9. Positive behavior support

10. Self-management training
مقلدمه

قلدرى' رفتار يرخاشــر انهاى اسـت كه بهطور عمدى، مكرر و بهقصـــ

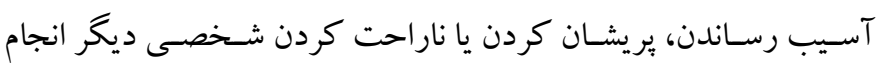

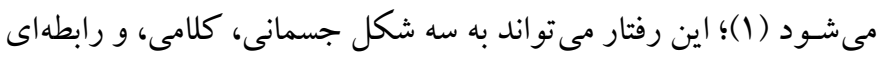

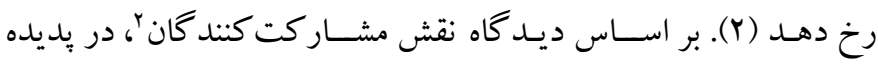
قلـدرى علاوه بر نقش هاى قلدر و قربانى، جهار نقش ديخر (كمكك كننده

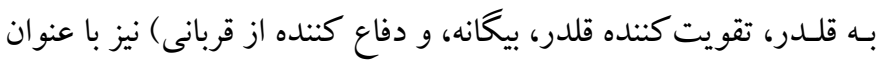

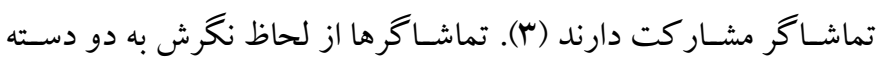

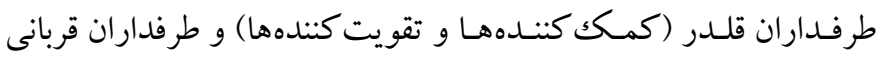

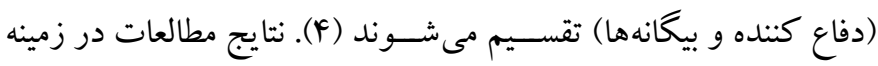
تفاوتهاى جنسيتى در انواع و شكلهاى مختلف قلدرى نشان داده است

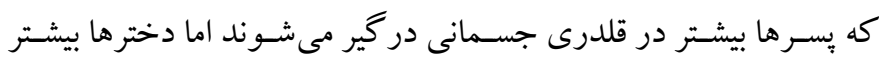

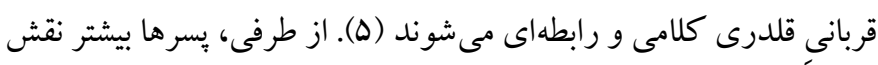

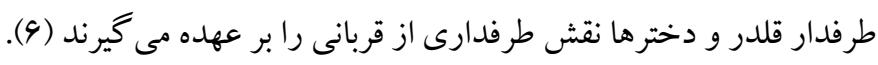

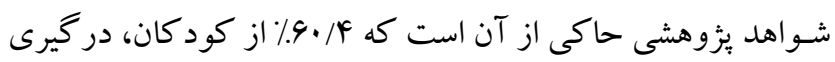

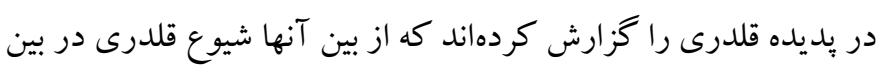

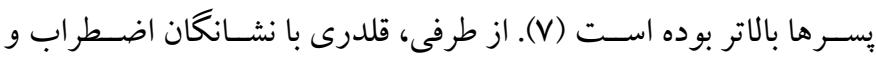

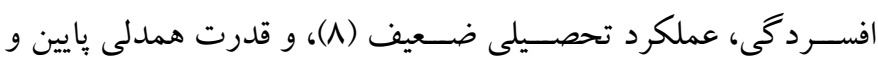

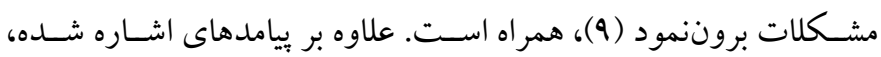
يُزوهشــر ان معتقدند كه قلدرى با تجارب كود كان از مدرسـه و عوامل

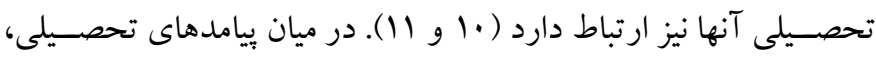

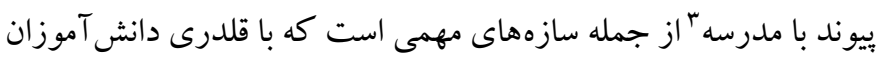
رابطه دارد (11 (I) (I). منظور از بيوند با مدرسـه، كيفيت ارتباطات دانش آموز با مدرسـه، الهـ

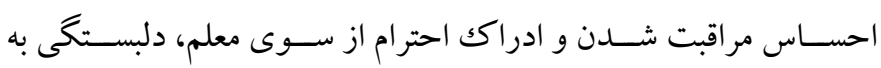
مدرسه، سطح مشار كت در مدرسه، و تعهل به ارزش ها و باورهاى مدرسه

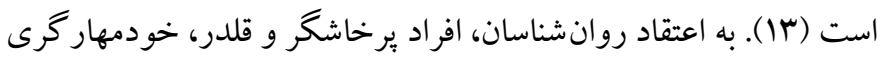

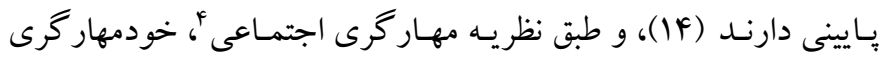

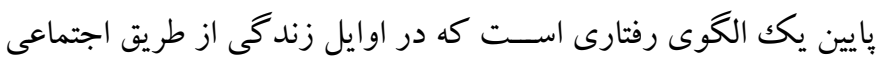

1. Bullying

2. Participant Role Approach

3. School bonding

4. Social Control Theory

5. Bully busters 


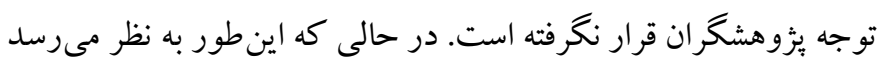

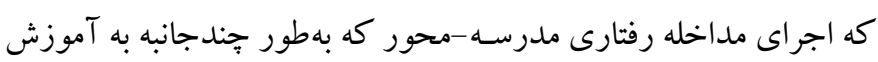

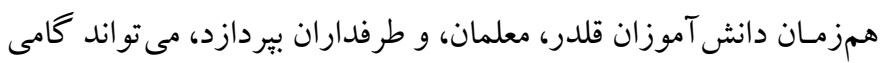

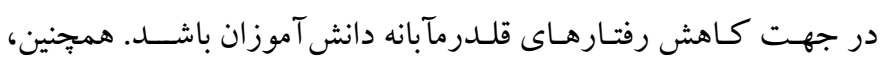

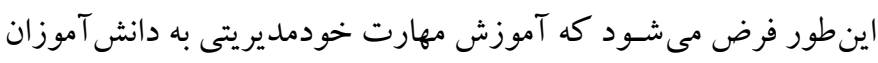

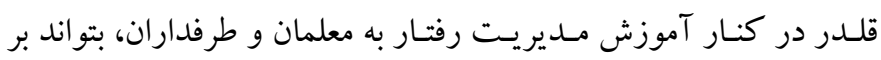

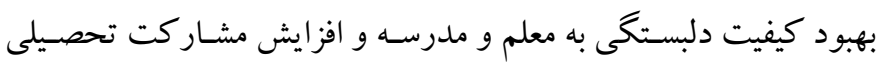

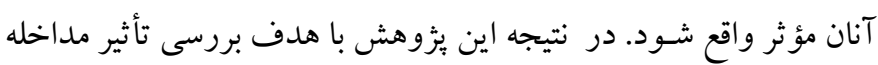

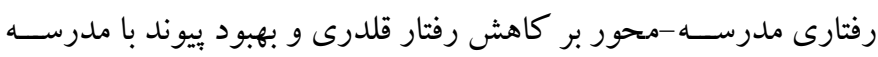
دانش آموزان قلدر، طراحى و اجرا شد.

روش

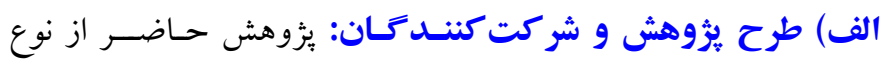

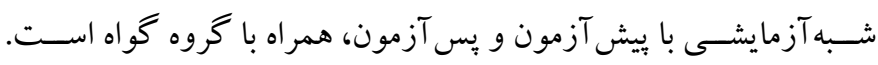

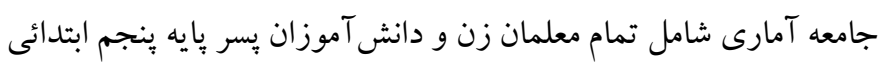

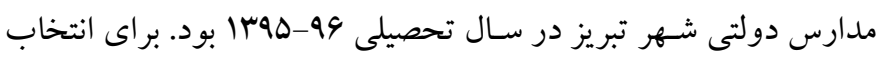

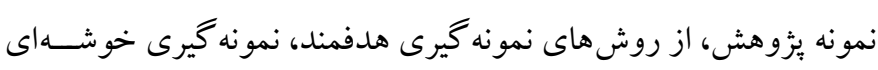

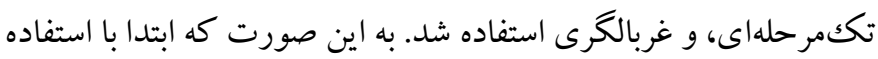

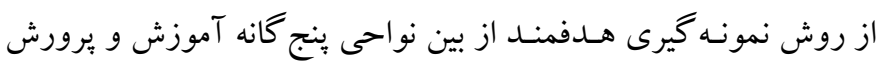

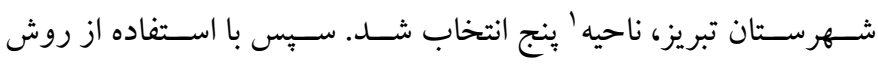

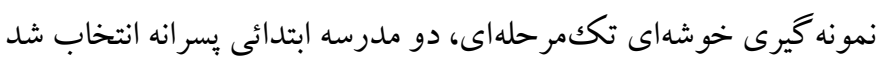

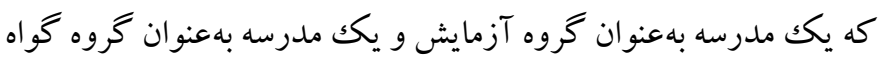

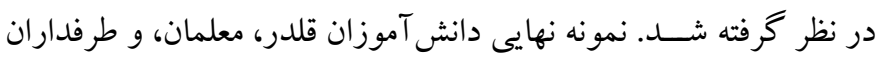

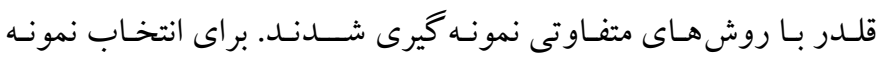

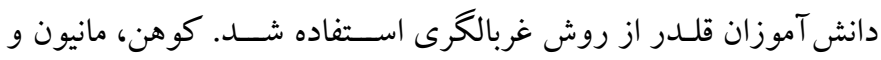

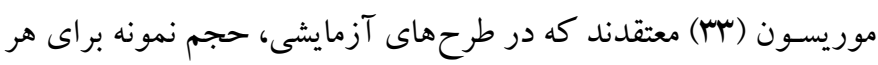
زيـر گروه، ها نفر كفـايست مى كنــ؛ بنـابراين از بين 199 دانش آموز

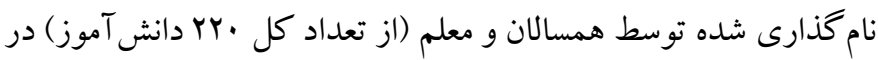

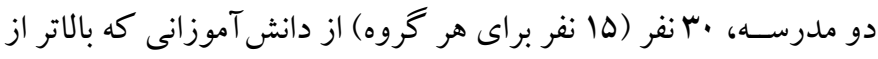

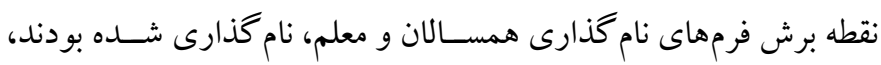

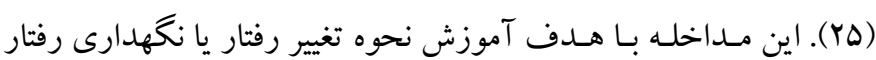
شـخصى طر احى شده است (Y)). مداخلات خود -مديريتى همواره مورد

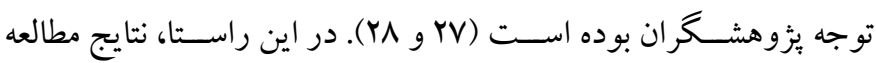

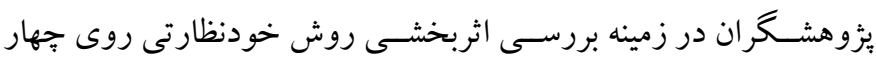

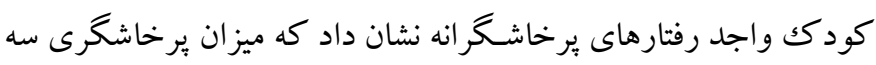
نفر از اين كود كان به سطح صفر رسيده است (YV). همجنين، در مطالعه مهنه

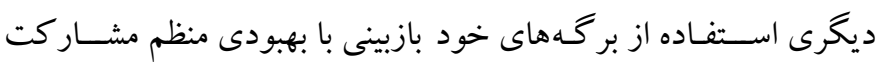
تحصيلى آزمودنى همر اه بوده است (Y^).

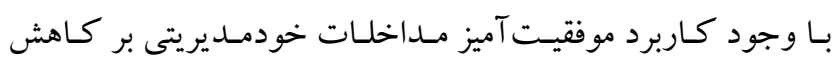

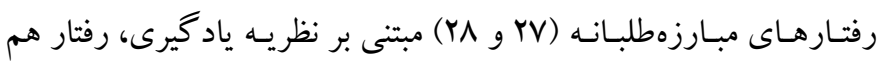

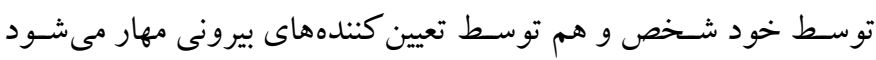

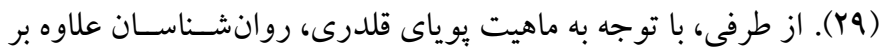

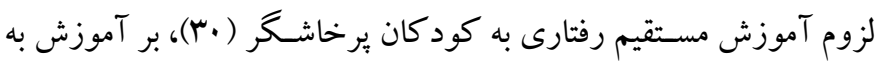

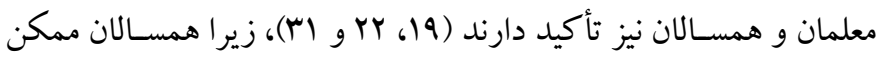

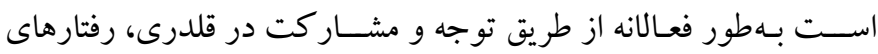

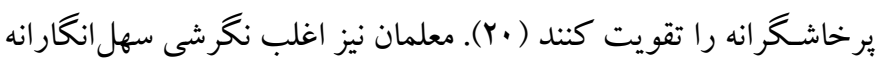
نسـبت به قلدرى دارند، يا اينكه از مداخلات خودسـرانه استفاده مى كنند كه اثرى منفى روى قلـدرى دارد (اس). در حسالى كـه مى توان از توجـهـ همسالان و معلمان در جهت غلبه يا كاهش اين رفتار استفاده كرد، در اين

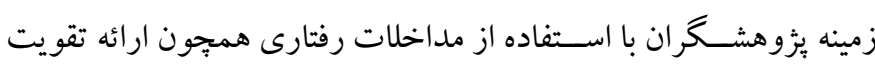
غيرمشروط و بازى رفتار خوب در كلاس، شاهد كاهش رفتار برخاشخرانه

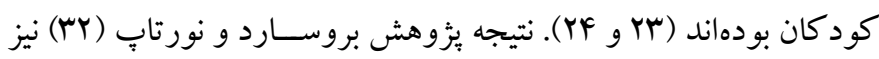

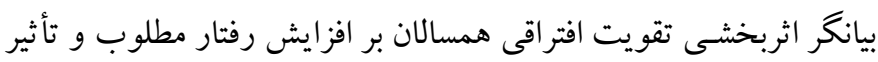
خاموشى بر كاهش اختلال هاى رفتارى مخرب كود كان بودهاند.

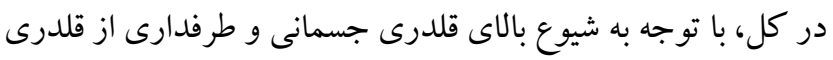

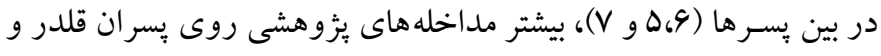

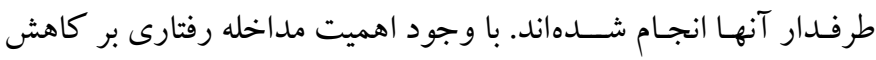

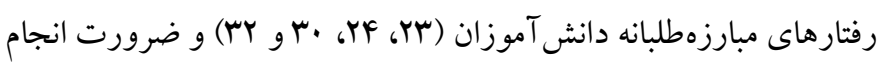

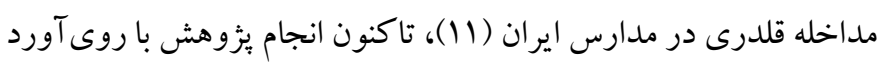
رفتارى و با هدف تغيير رفتار دانش آموزان واجد رفتارهاى قلدرى مدر، مورد

ا. دليل انتخاب ناحيه ها اين بود كه بعد از انجام مطالعات مقدماتى توسط يزوهشخران، مشخص إنص شد كه شيوع قلدرى در اين ناحيه بالا است. 
دانش آموز قلـدر، F معلم، و ها دانش آموز طرفـدار تشــكيـل دادنـد. آزمودنى هاى گروه گواه نيز فقط شامل ها دانش آموز قلدر بود.

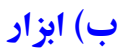

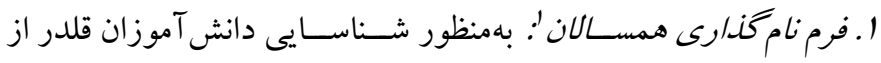

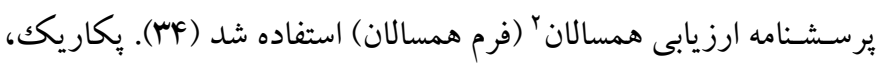
يرينز، ليبرت، وينتراب و نيلدر سال $19 V 9$ فرم همسالان يرسشنامه ارزيابى همســالان را با هدف اندازه گيرى ميزان ســازش يافتكى (يرخاشــرى، كناره گيرى، و محبوبيت) كود كان پايه اول تا نهم از سـوى همكلاسـىها طراحى كردند. اين فرم شامل F IF كويه است (MF) كه در يُزوهش حاضر فقط از ب كويه مربوط به خردهمقياس برخاشگرى در قالب فرم نام گذارى اسـتفاده شـد. به اين صسورت كه از دانش آموزان خواسـته شـد تا اسـامى همكلاسـى هايیى كه رفتارهاى موجود در فرم نام كذارى را دارند، به طور مشـخص بنويسـند. يكاريكك و همكاران (MF) ضـريب آلفاى كرونباخ را

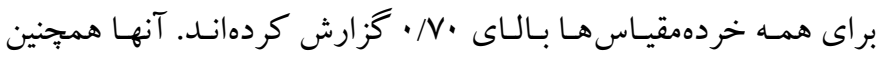

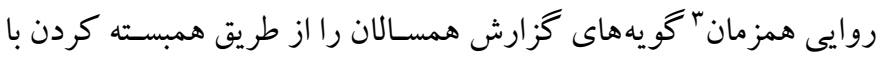

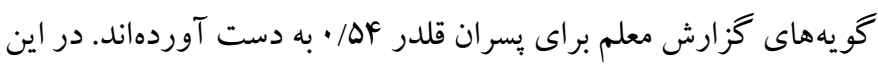

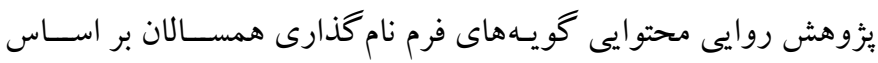
نظرات • ا متخصص و با محاسبه شاخص نسبت روايى محتواء مورد تأييد قرار كرفت (CVR=·/A). بهمنظور بررســى ميزان توافق بين همســالان ارزياب در نام گذارى هر همكلاسـى خاص (بهعنوان قلدر)، از اعتبار بين مشـاهده كنند كانه استفاده شد كه نتيجه ضريب كايا براى كويه هاى فرم نام كذارى همسـالان بين سع/ • تا \&\&/ • به دست آمد كه توافق خوب بين مشاهده كنند كان را نشان مى دهد. مبتنى بر بيشينه يزٔوهشى (سو هץ) نقطه برش يُزوهش براى اين فرم در تر كيـبـ بـا فرم نـام گَذارى معلم، انتخاب دانش آموزانى بود كه توسـط ·ب درصــ همسـالان و معلم بهعنوان قلدر

$$
\text { انتخاب شده بودند. }
$$

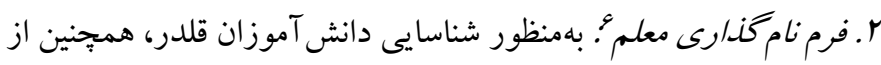

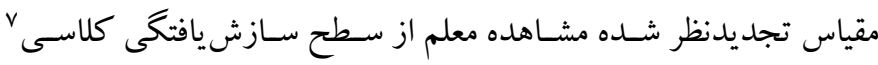
اسـتفاده شـد. اين مقياس در سـال 1991 توسط ورتايمر -لارسون، كلام و

5.Inter-rater or observer reliability

6. Teacher Nomination Form

7. Teacher Observation of Classroom Adaptation-Revised (TOCA-R)

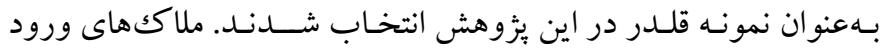
آزمودنى هاى قلدر شـامل: () جنسـيت بسر، Y) دريافت تشخيص قلدر بر اســاس فرمهاى نام كذارى معلم و همســالان، ب) تحصــيل در پيايه ينجم ابتدائى، \&) تحصيل در مدرسه دولتى ناحيه هـ آموزش و يرورش شهرستان تبريز، و ه) عدم مصــرف داروهاى روانيزشـكى؛ و ملاككهاى خروج شــامل: () داشــتن اختلالات شــــيد همجون اختلال رفتارى ناهنجارى، نافرمانى مقابلهاى، اضـطراب، و افسردگگى، Y) داشـتن مشـكل جسـمى يا بيمارى يزشكى كه مانع شركت منظم در جلسات مداخله شود، و س) عدم تمايل به ادامه همكارى بود.

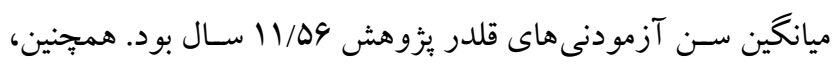

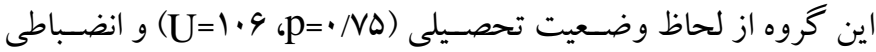

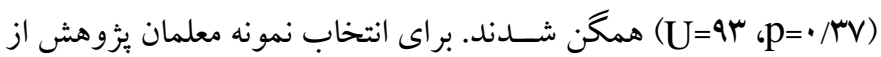
روش نمونه گيرى هدفمند اسـتفاده شــد. به اين صــورت كه جون نمونه نهايى قلدر در كروه آزمايشـى از F كلاس انتخاب شـده بودند، در نتيجه معلمـان هر F كلـاس بـه روش هدفمند انتخاب شــــند. ملاككهاى ورود آزمودنى هاى معلم شــامل: ( ) جنســيت خانم، Y) داشــتن حداقل يكك دانش آموز شـناسايى شده بهعنوان قلدر در كلاس،ب) داشتن حداقل يكك دانش آموز شـناسـايى شـده بهعنوان طرفدار قلدر در كلاس، و \&) تعهل و تمـايسل بـه همكـارى بـا يثزوهش؛ و ملـاكك خروج، عـدم تمـايل به ادامه همكارى بود. ميـانكين ســن آزمودنى هاى معلم در اين بثزوهش Fr/Fr ســال بود. در نهايــت، دانش آموزان طرفـدار قلـدر با اســتفاده از روش غربالكرى انتخاب شـدند. به اين صورت كه ها نفر از دانش آموزانى كه با استفاده از روش نام گذارى همسالان، بالاتر از نقطه برش فرم نام گذارى در هر كلاس قرار داشـتند، انتخاب شــند (فقط براى گروه آزمايشـى). ملـاكك هـاى ورود و خروج طرفداران قلدر مشــابه نمونه قلدر بود، با اين تفاوت كه براى طرفداران قلدر، ملاكك ورودى دريافت اين تشــيص بر اساس فرم نام كذارى همسالان انجام شد. همجينين، ميانگين سن طرفداران قلـدر س/11/ ســال بود. در كـل، آزمودنىهـاى كروه آزمايشــى را ها

1. Peer Nomination Form

2. Peer Assessment Inventory

3. Concurrent validity

4. Content Validity Ratio (CVR) 


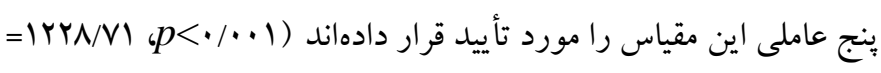

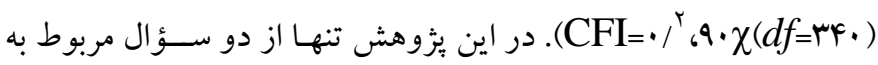

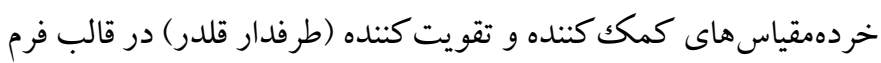

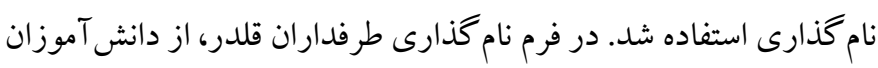

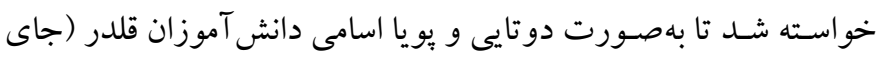

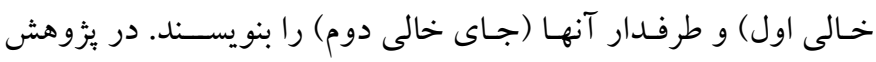

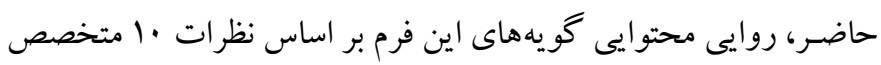

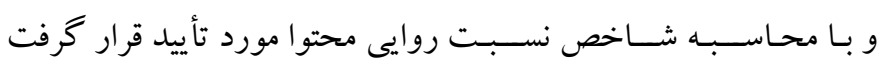
(CVR=·/A • )

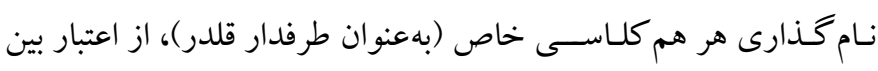

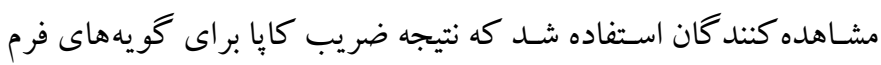

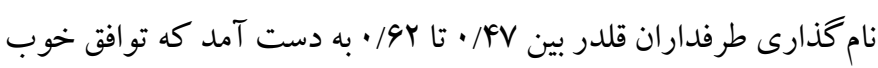

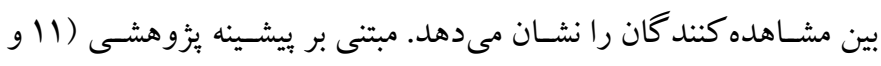

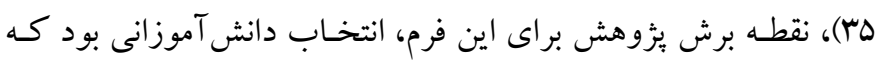

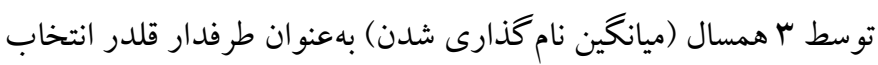
شده بودند.

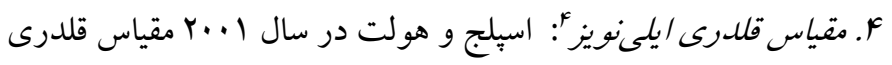

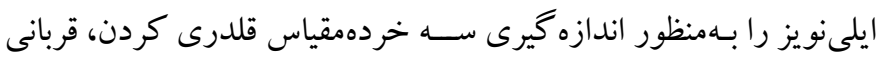

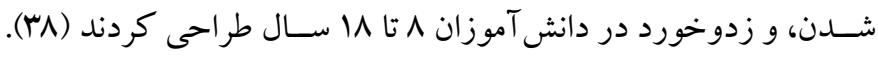

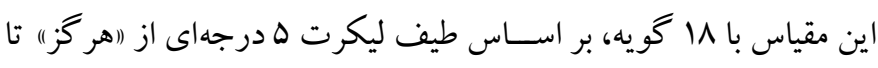

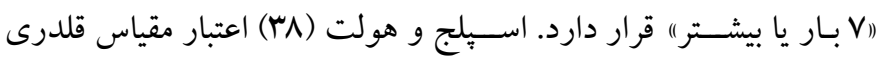

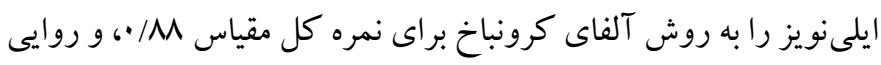

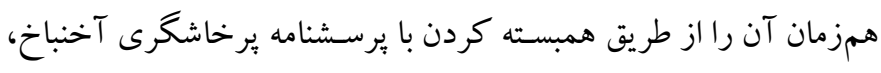

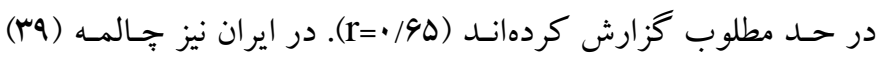

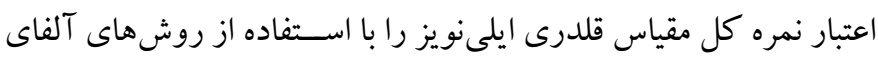

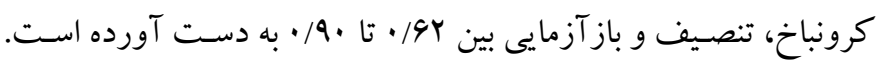

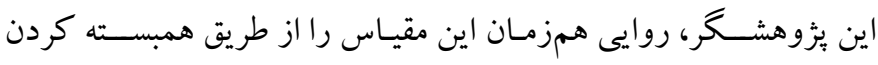

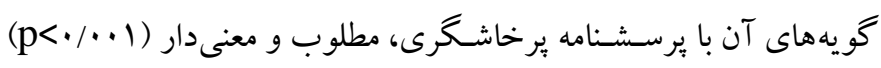

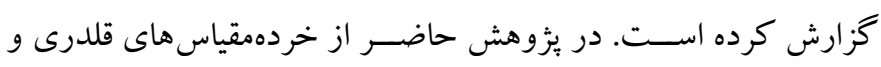

ويلر (4) بهمنظور اندازه گيرى شـايستخى عملكرد كود كان در تكاليف مهم (سه خردهمقياس ارتباط اجتماعى در برابر شرمزدگى، رفتار مقتدرانه

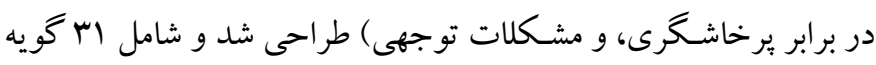

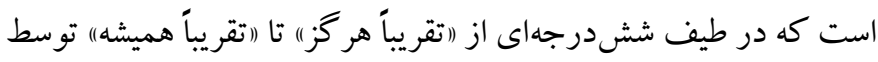

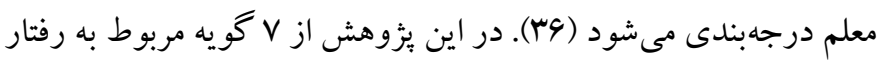

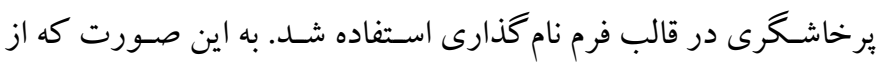

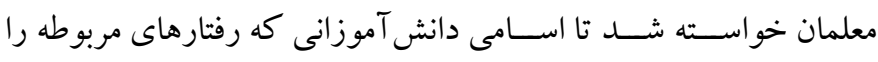

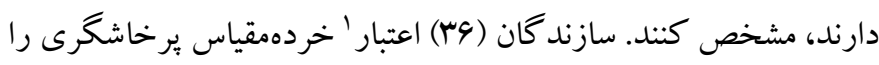

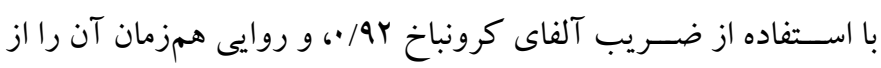

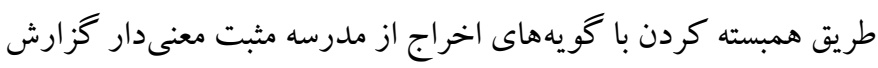

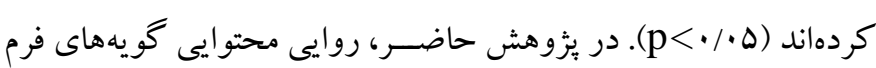

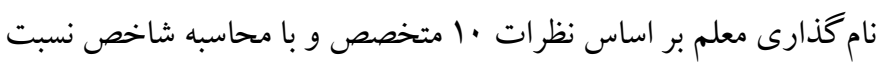

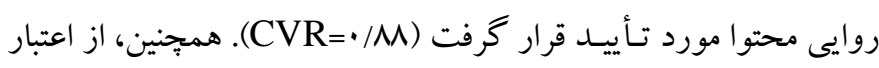

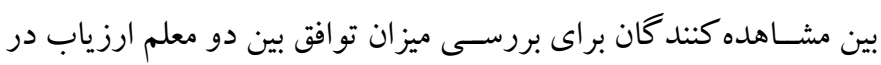

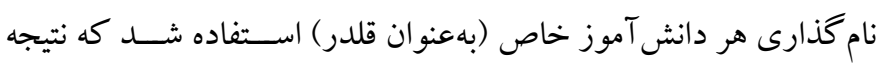

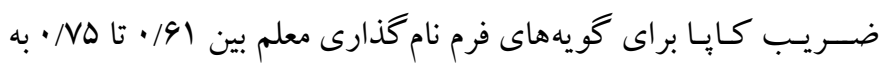

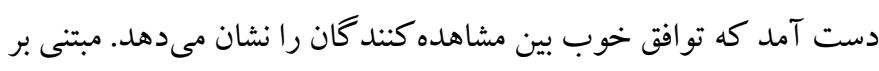

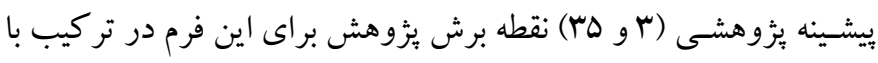

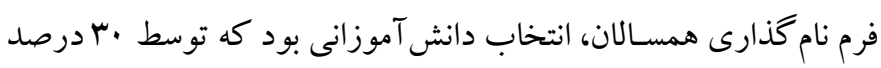

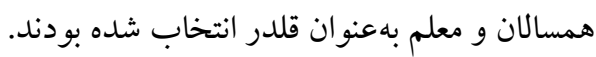

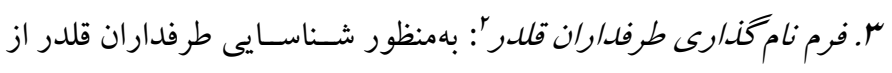

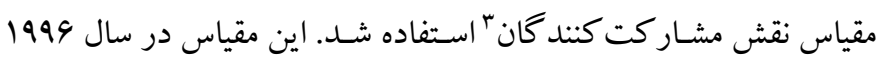

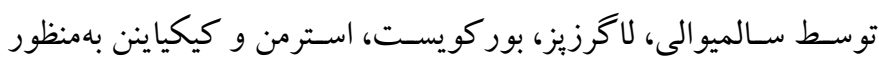

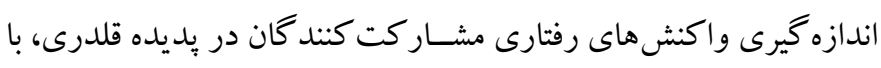

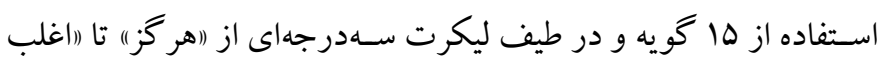

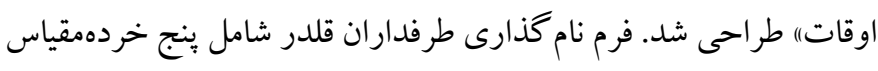

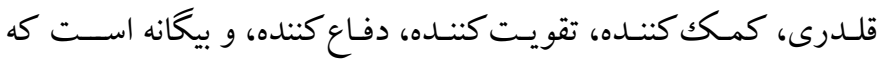

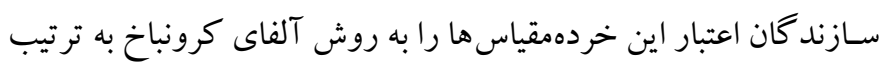

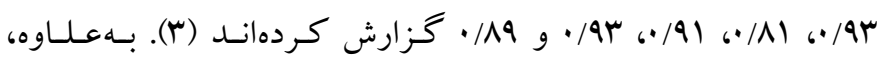

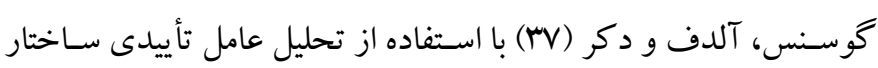


ج) برنامه مداخلهاى: مداخله رفتارى مدرسـه-محور يثوهش حاضـر با

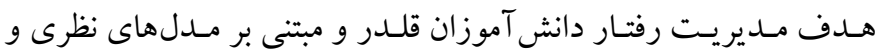

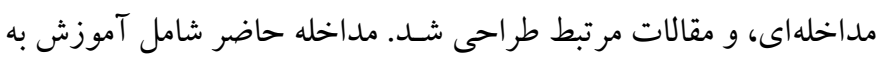

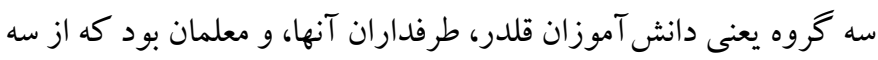

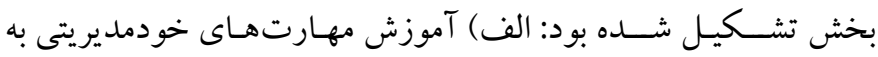
دانش آموزان قلـدر (مبتنى بر برنـامهـهـاى خودمديريتى آلبرتو و تورتمن

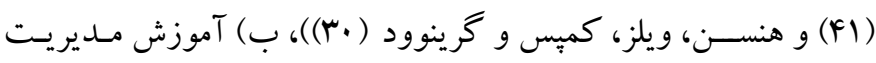

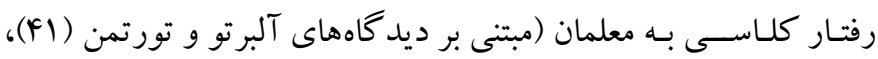

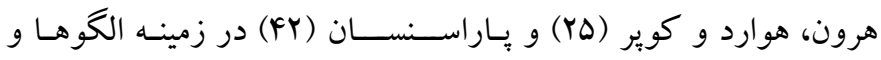

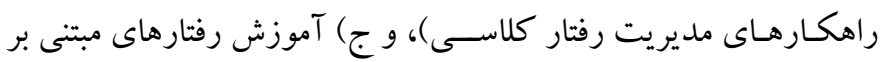

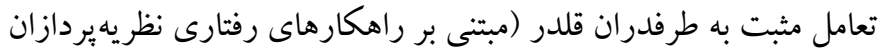

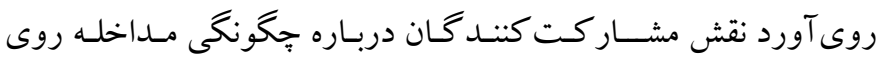

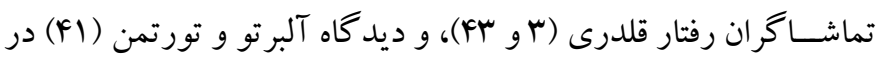
زمينه تقويت افتراقى). محتواى مداخله ها توسط نويسنده اول ئزوهش در

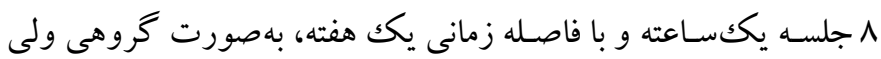

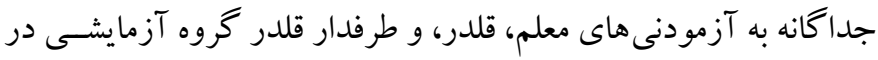
مدرسه ارائه شد. مداخله ها در ساعات غير كلاسى انجام شد و للازم به ذكر معرك

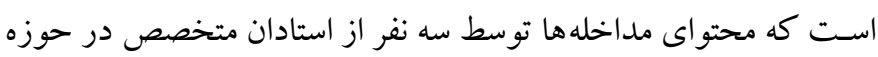

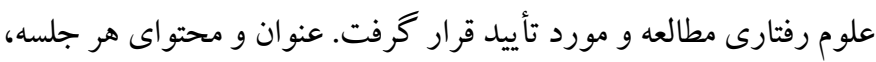
به تفكيك نوع مداخله در جدول ب ارائه شده است.
زدوخورد استفاده شد. اعتبار اين خردهمقياسها با استفاده از روش آلفاى

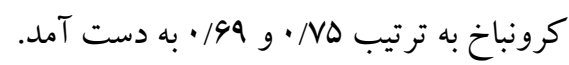

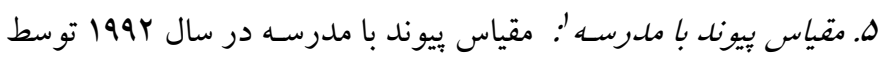

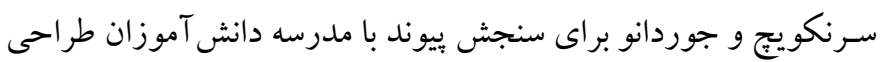

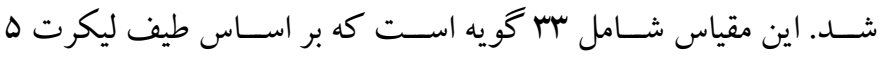

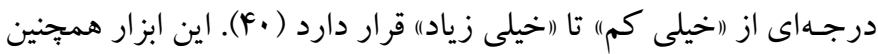
شـامل هفت خردهمقياس دلبستخى به مدرسه، دلبستخى به معلمان، تعهد

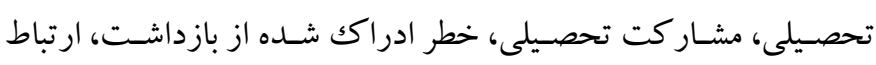
والدينى، و فرصـت ادراكك شـده اسـت كه اعتبار جهار خردهمقياس اول

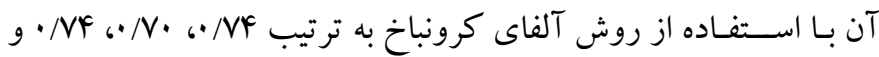

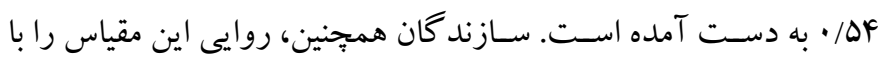
اسـتفاده از تحليل عاملى اكتشـافى و تأييدى بررسـى كردهاند كه نتايج

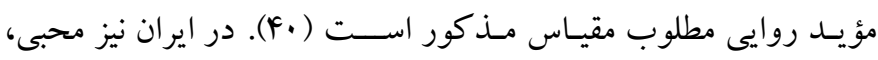

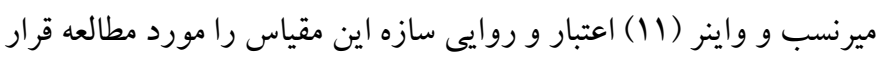

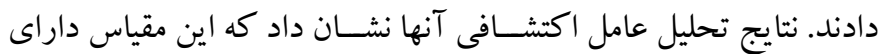

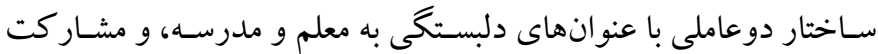
تحصسيلى اسـت. آنها همجنين، اعتبار اين خردهمقياس ها را با اسـتفاده از

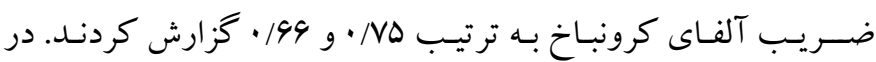

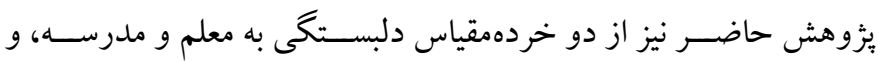
مشاركت تحصيلى استفاده شد كه اعتبار اين خردهمقياس ها با استفاده از روش آلفاى كرونباخ به ترتيب rA/ • و VN/ • به دست آمد.

جدول r: اطلاعات مربوط به مداخله رفتارى مدرسه-محور يزوهش

\begin{tabular}{|c|c|c|c|c|c|}
\hline كرووه هدف: دانش آموزان قلدر & & & ن مداخله: آموزش مهارت خود-مديريتى & عنو & \\
\hline محتوا و تكليف & هدف & 疋 & محتوا و تكليف & هدف & $\frac{1}{3}$ \\
\hline 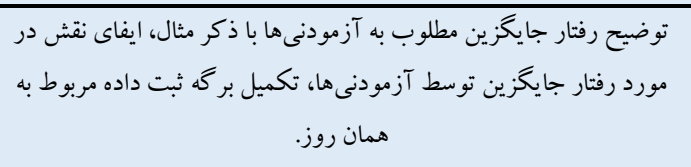 & 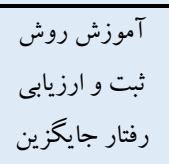 & $\Delta$ & 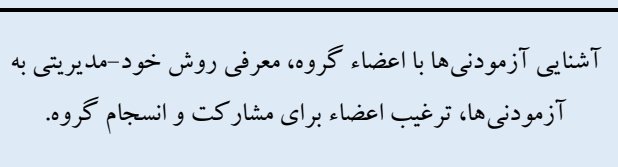 & آشاد آنايى با & 1 \\
\hline 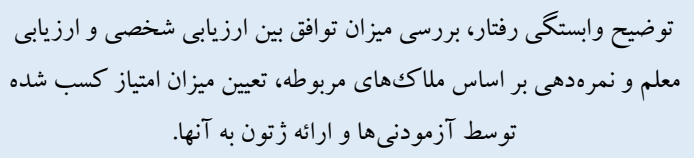 & تقنايى با روش & 4 & 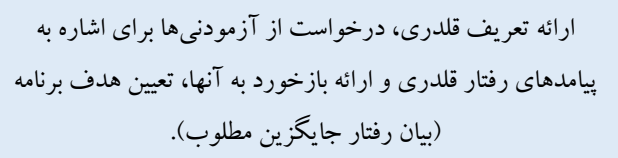 & هدف كزينى آشنايى & r \\
\hline
\end{tabular}


ارزيابى بر گه ثبت داده جديد و بررسى ميزان انطباق آن با ارزيابى معلم، توضيح در مورد شرايط تقويت (دريافت امتياز) و تنبيه شدن (كسر امتياز)

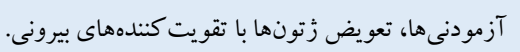

آموزش راهبردهاى آموزش به خود به آزمودنىها، تمرين اين مهارت ها در

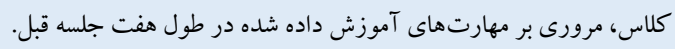

$$
\text { كروه هدف: معلمان }
$$

محتواو تكليف

آموزش راهكارهاى مديريت مثبت كلاسى بيشايندمحور (مثل تعيين قوانين

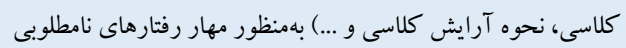

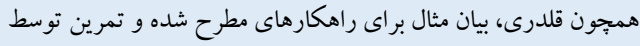

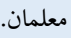

آموزش انواع تقويت كنندهاى كار آمد در كلاس و اهميت ارائه بازخورد

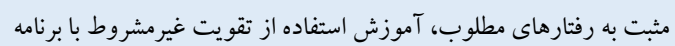
زمانى متغير روى دانش آموزان واجد مشكلات انضباطى در كلاس. آموزش نحوه اجراى بازى رفتار خوب و جِكونگى توزيع امتيازها بين دانش آموزان در كلاس.

مرورى بر جلسات قبل، اشاره به مداخلات كار آمد براى دانش آموزان قلدر

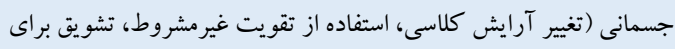

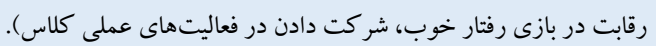

$$
\text { خروه هدف: طرفداران قلدر }
$$

آموزش انواع نقش هاى تماشاكر قلدرى (بيكانهها، تقويت كنندها،

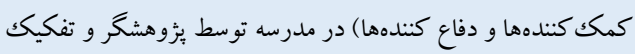

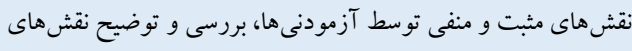

$$
\text { مطرح بر اساس هنجارها و قو انين مدرسه. }
$$

اشاره به رفتارهاى جرئت مندانه، منفعلانه و يرخاشخرانه از طريق ايفاى نقش

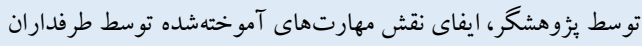

$$
\text { قلدر در مورد رفتارهاى يرخاشگر انه در مدرسه. }
$$

آموزش نحوه تقويت افتراقى جفت قلدر خويش، نمايش نحوه اجراى

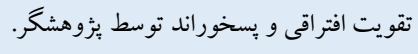

مرور مهارت هاى آموختهشده، بيان كاربرد مهارتهاى آموخته شده در

$$
\text { زندگى شخصى. }
$$

آشنايى با روش تنبيه خود

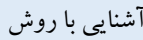

آموزش خود و

مرورى بر جلسات

هدف

آموزش مديريت

رفتار كلاس با موزي

تأكيد بر

يشيشايندهاى رفتار

آموزش مديريت

رفتار كلاس با مدوند

تأكيد بر نقش

تقويت كنندهها

آموزش نحوه

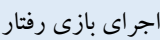

خوب در كلاس بازي

مرورى بر

مداخلات كار آمد و ناكار آمد در كرات

قلدرى

هدف

آموزش

مسئوليتيذيرى إنوتئ

اجتماعى مستص

آموزش

مهارتهاى أموتر

جرأتورزى

آموزش تقويت

افتراقى

مرورى بر جلسات
توزيع بر كهاى ثبت داده بين آزمودنىها، توضيح در مورد نحوه

v

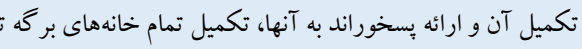

هفته بعد.

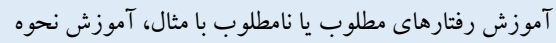

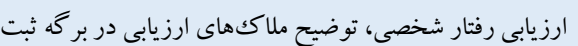

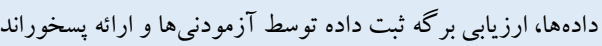

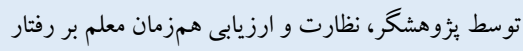

آزمودنى ها.

عنوان مداخله: آموزش مديريت رفتار كلاسى أمودي

s.

محتواو تكليف

هدف

آموزش نحوه

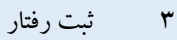

خود

آموزش شيوه

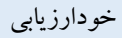

بيان اهداف اختصاصى مداخله، ايجاد تفاهم و انسجام بين اعضاء

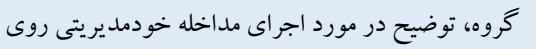

$\Delta$

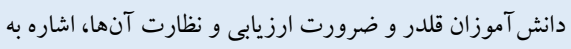

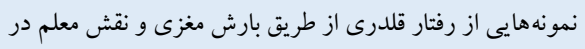

بيشخيرى و كاهش آن.

ارائه تعريفى از قلدرى، انواع آن و ييامدهاى منفى قلدرى، آموزش

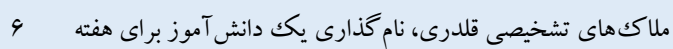

$$
\text { بعل بر اساس ملاككهاى مذكور. }
$$

آشنايى با

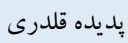

آموزش توالى بيشايند، جرايى و ييامد رفتار، درخواست ارائه مثال

V

ب-B-C

آشنايى با

فرآيند

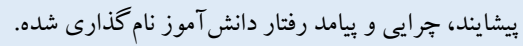

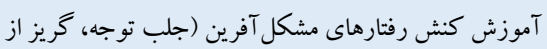

تكليف، به دست آوردن اشياء ملموس و تقويت حسى)، ارائه مثال

براى كنش هاى مختلف از سوى معلمان و ارائه بازخورد به آنها،

$$
\text { بر رسى كنش رفتارى دانش آموز نام گذارى شده. }
$$

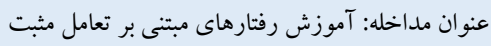

محتواو تكليف

هدف

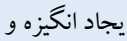

آشنايى آزمودنىها با ساير اعضاء گروه، ترغيب اعضاء براى

$\Delta$

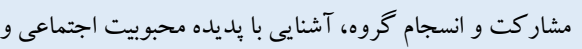

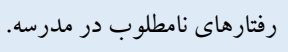

آشنايى باد آنجزه

محبوبيت

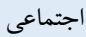

$$
\text { آشنايى با رفتارهاى قلدرى و انواع (جسمانى، كلامى و }
$$

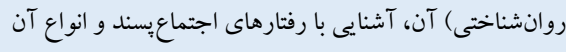

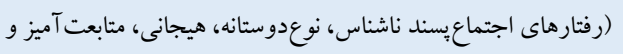

رفتارهاى اجتماعيسند در موقعيتهاى بحرانى).

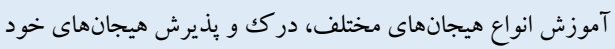

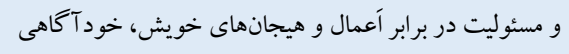

$$
\text { هيجانى و مديريت بهموقع آن. }
$$

اشاره به يِامدهاى منفى قلدرى توسط طرفداران قلدر با استفاده از

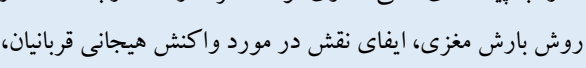

$$
\text { نحوه همدلى عاطفى و شناختى با قربانيان. }
$$

آشنايى با رفتار

r اجتماعيسند و

رفتار قلدرى

آموزش

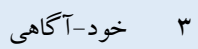

هيجانى

آشنايى با هيجاني

بيامدهاى

قلدرى روى

قربانيان 


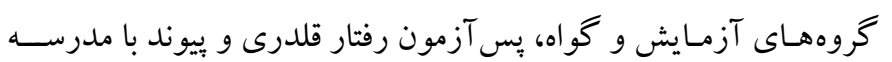

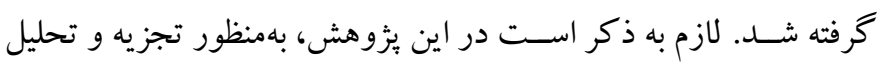

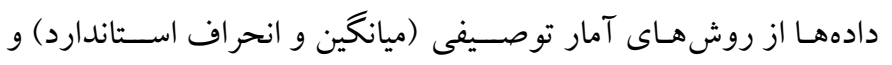
استباطى (تحليل كوواريانس جندمتغيرى يا مانكوا) استفاده شد.

\section{يافتهها}

ميانگين و انحراف اســاندارد نمرات بيش آزمون و بس آزمون متغيرهاى

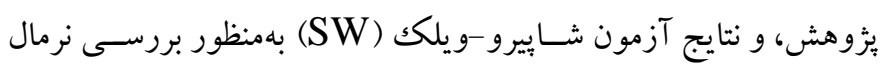

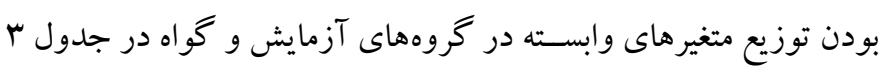
ارائه شده است.
د) روش اجرا: بِ از اخذ مجوزهاى لازم از دانشگاه تبريز و سبس اداره

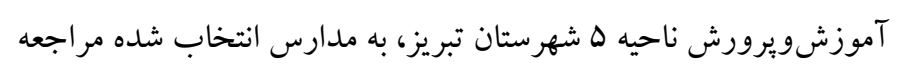

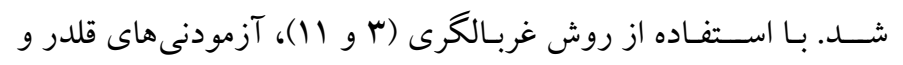

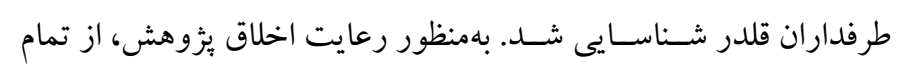

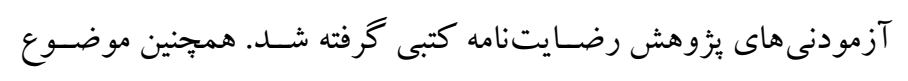

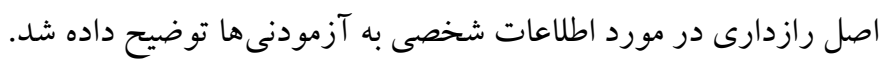

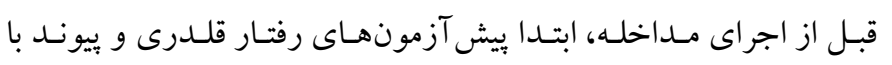

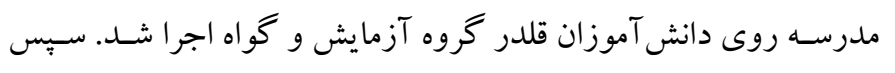

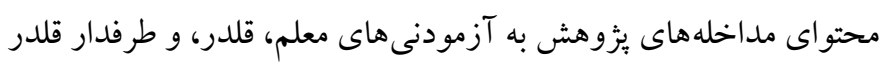

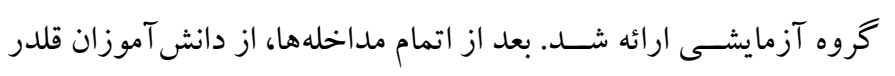

جدول r: شاخصهاى توصيفى نمرات بيش آزمون-بس آزمون در كروههاى آزمايش و كواه (·-r=r)

\begin{tabular}{|c|c|c|c|c|c|c|}
\hline $\mathbf{p}$ & SW & انحراف استاندارد & ميانكين & كروه & وضعيت & متغيرها \\
\hline$\cdot / \Delta$ &.$/ 99$ & $9 / \pi q$ & $18 / 99$ & آزمايش & \multirow{2}{*}{ ي بيش آزمون } & \multirow{4}{*}{ 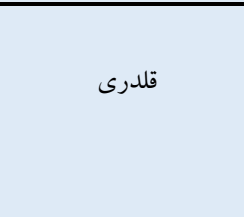 } \\
\hline$\cdot$. NQ &.$/ 9 V$ & $9 / 4 \lambda$ & $19 / \pi r$ & كواه & & \\
\hline.$/ 4 r$ &.$/ 90$ & 1/9r & $11 / \Lambda$. & آزمايش & \multirow{2}{*}{ ع عس آزمون } & \\
\hline$\cdot / 94$ &.$/ 99$ & $\Lambda / \cdot 1$ & 19/1. & 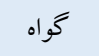 & & \\
\hline$\cdot / r$ &.$/ 90$ & $\Delta / I V$ & $1 F / 9$. & آزمايش & \multirow{2}{*}{ ي يش آزمون } & \multirow{4}{*}{ زدوخورد } \\
\hline r &.$/ 94$ & r/va & $\mid r / \pi r$ & كواه & & \\
\hline$\cdot / r$ &.$/ 90$ & $r / q q$ & N/99 & آزمايش & \multirow{2}{*}{ ع بس آزمون } & \\
\hline$\cdot 11$ &.$/ 94$ & $4 / .4$ & $\mid r / 4$. & 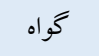 & & \\
\hline •/Ir &.$/ 94$ & F/ND & $F_{N} /$ & آزمايش & \multirow{2}{*}{ ي بيش آزمون } & \multirow{4}{*}{ دلبستخى به معلم و مدرسه } \\
\hline$\cdot / 10$ &.$/ 90$ & $V / \pi \Delta$ & FA/YG & 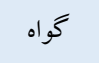 & & \\
\hline$\cdot \pi r$ &.$/ 99$ & $r / Y \Lambda$ & $\Delta 1 / .9$ & آزمايش & \multirow{2}{*}{ ي بس آزمون } & \\
\hline$\cdot 119$ &.$/ 90$ & $V / 9$. & $r \Delta / \Delta r$ & 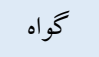 & & \\
\hline . &.$/ 99$ & $F / M$ & IN/Dr & آزمايش & \multirow{2}{*}{ يش آزمون } & \multirow{4}{*}{ مشار كت تحصيلى } \\
\hline$\bullet \bullet \vee$ & . & F/FT & 1N/9T & كواه & & \\
\hline$\cdot \mid k r$ &.$/ 99$ & 1/90 & rQ/N9 & آزمايش & \multirow{2}{*}{ پس آزمون } & \\
\hline$\cdot / \mathrm{VV}$ &.$/ 90$ & $\Delta / \Delta r$ & $19 / 9$. & كواه & & \\
\hline
\end{tabular}

بررسـى قرار گرفـت. به اين صسورت كه ييش فرض نرمال بودن توزيع

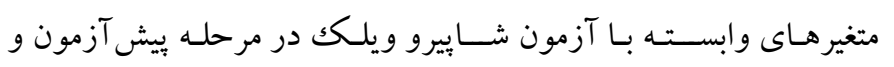

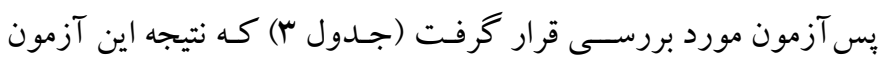

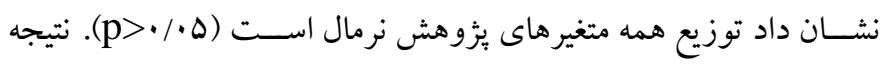

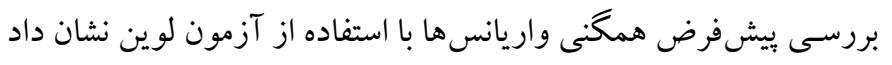

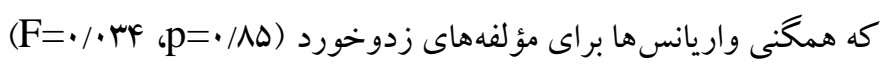

مطابق بـا نتايج جدول سا، ميانگگين نمره قلدرى و زدوخورد در گروه

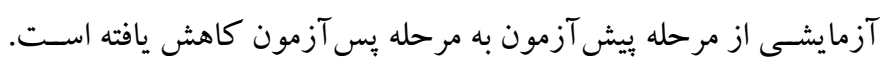

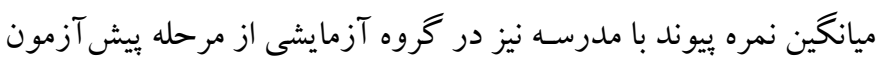

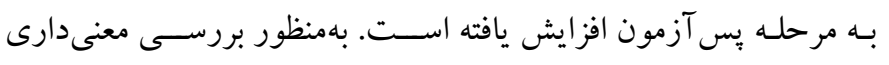

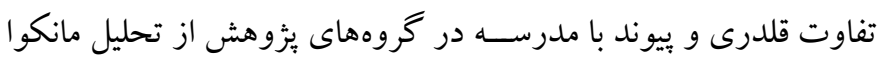

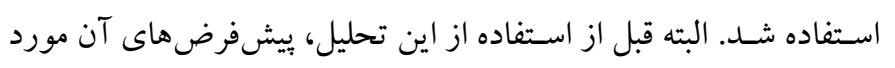


كروههـا همخن نيسـت، زيرا F مربوط بـه آزمون امبـاكس در سـطح

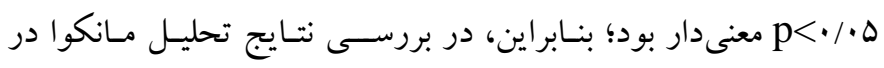

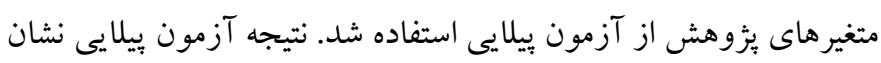

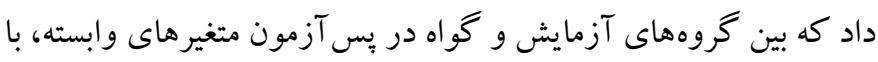

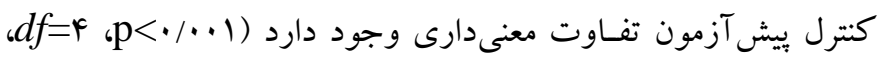
90 F=9/VA درصد از واريانس مربوط به متغيرهاى قلدرى و يويوند با مدرسه ناشى از

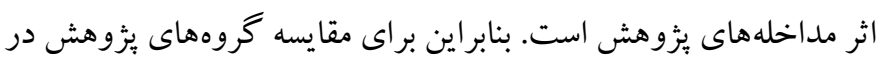

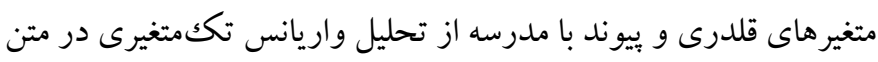

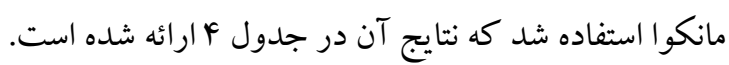

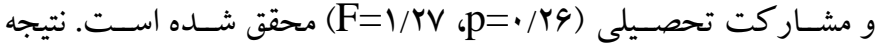
مربوط به ييش فرض همبستخى متعارف بين متغيرهاى وابسته نيز از طريق

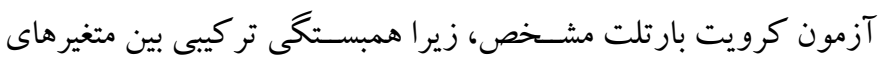

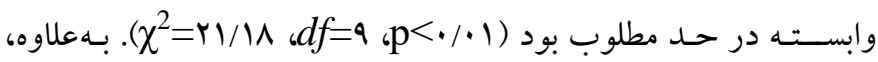

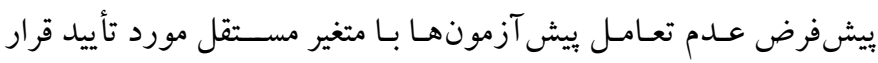

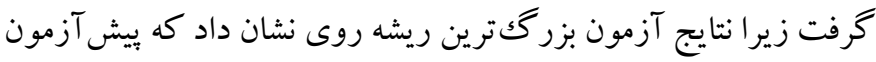

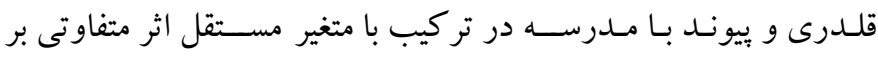

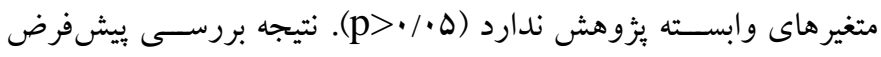

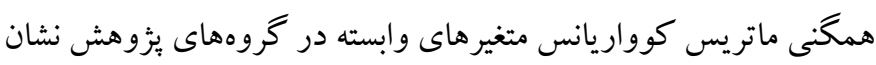

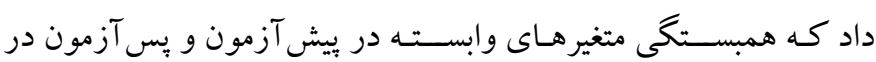

جدول ع: نتايج تحليل واريانس تككتغيرى تفاوت تروهها در مؤلفههاى قلدرى و ييوند با مدرسه

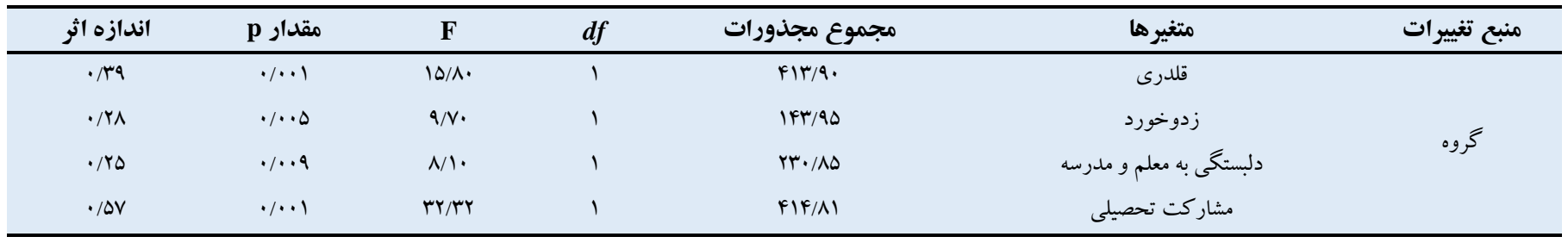

رفتارهاى مخرب كز ارش كردهاند، همسـو اسـت. اين مطالعات همجِنين اثربخشى مداخله رفتارى جندجانبه مدرسه-محور را بر كاهش قلدرى و زدوخورد كودكـان تـأييـد كردهانـد. در اين زمينـه، روس و هورنر (YY) معتقــنـــ كـه طرح حمـايــت رفتـارى مثبـت به دليل اينكه باعث افز ايش ياسـخ هاى مناسب تماشاگرها و قربانيان قلدرى مىشود و اين امر احتمال

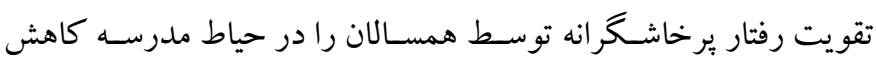
مىدهـد، در نتيجه مداخلهاى اثربخش اســت. آلن ( آس) نيز بر اين اعتقاد اســت كه قلدرى در خلاً اتفاق نمىافتد، كه عوامل متعددى در بروز آن مشــاركت دارند و يكى از مهم ترين آنها نحوه مديريت كلاسـى معلم و نحوه ياسـخگ يُى وى به رفتارهاى نامطلوب دانش آموزان اسـت. عدهاى ديخر از يزوهشـحران نيز با اشـاره به نقش همسـالان در بروز رويدادهاى قلدرى، به اين نكته اشـاره كردهاند كه همسالان بهويزه طرفداران قلدر از طريق تشويق و كمككرسانى، به تأييد رفتار قلدرها در مدرسه مى بردازند كه اين مسئله بر ضرورت توجه به نقش تماشاخر ها در مداخله هاى قلدرى اشـاره دارد (r و (Y). به عبارتى، اولين يافته يزوهش همسـو با مطالعات قبلى، بر اين ديــــاه كـه قلـدرى مـدرســه-محور بـه دليل اثريذيرى از
مبتنى بر مندرجات جدول \&)، بين گروههاى آزمايش و گواه از لحاظ يس آزمون قلدرى، زدوخورد، دلبستخى به معلم و مدرسـه، و مشـار كت

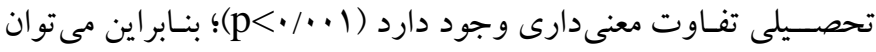
بيـان كرد كـه مـداخلـه رفتـارى مـــرســهـ-محور باعث كاهش قلدرى و زدوخورد و بهبود دلبستـكى به معلم و مدرسـهـه و مشــاركت تحصـيلى دانش آموزان قلدر گروه آزمايش شده است.

\section{بحث و نتيجه تيرى} هـدف يثزوهش حـاضـــر طراحى و ارزيـابى اثربخشــى مـداخله رفتارى مـدرســهـمحور بر كـاهش رفتـار قلـدرى و بهبود بيونسـ با مدرســـه در دانش آموزان قلـدر بود. يافته اول بززوهش نشــان داد كه مداخله رفتارى مدرســه-محور باعث كاهش قلدرى و زدوخورد در دانش آموزان قلدر شده است. اين يافته با نتايج مطالعات بروسارد و نورتابٍ (Yr)، برو كس و

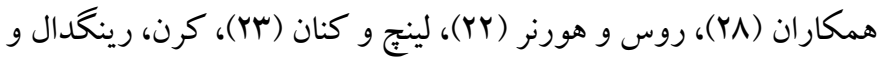
هيلت (YV)، و و الاكك و همكاران (YF) كه اثربخشى مداخلات رفتارى را

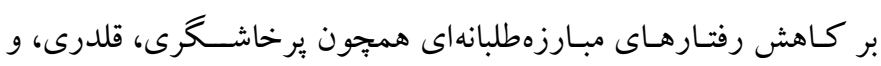


يافتهاى اين يزوهش ها همسـو اسـت و اثربخشـى مداخله رفتارى را بر

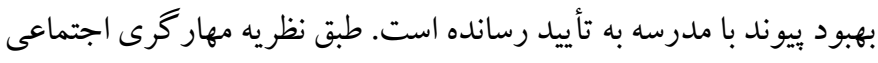

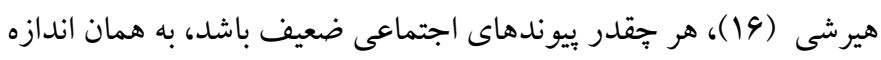

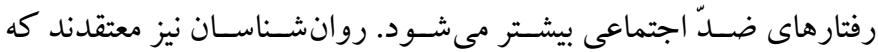

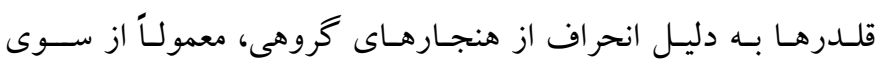

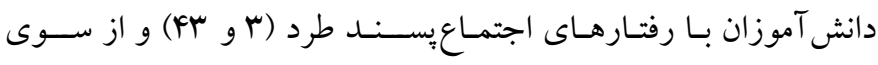
دانش آموزانى كـه گرايش طرفـدارى از قلدرى دارند، حمايت و تقويت

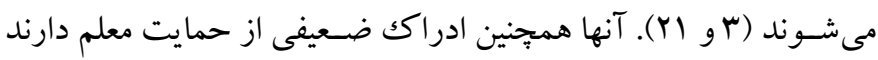

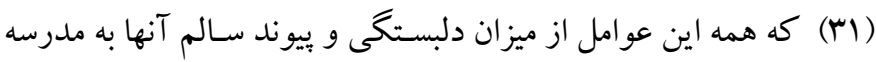

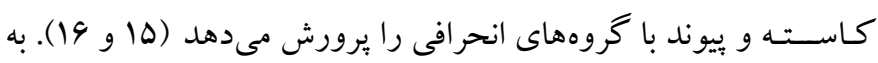

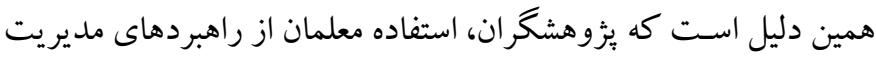
كلاسـى مثبت، راهبردهاى آموزشسى واكنشســاز يا فعالانه و ياد گيرى

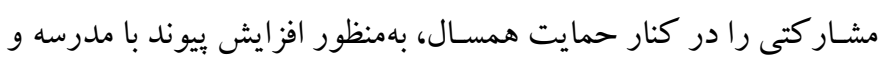

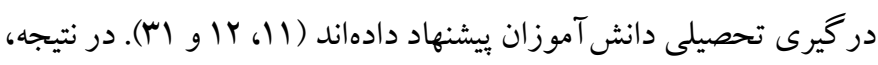
مى توان جنين اسـتباط كرد كه ارتباط عاطفى بين نوجوان و افراد مرسوم

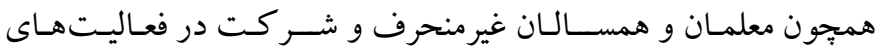
فوقبرنـامه، زمان در دســترس نوجوان را براى مشــار كت در رفتارهاى

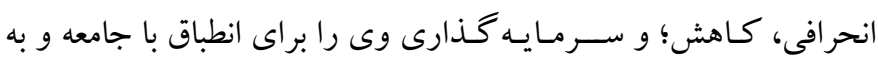

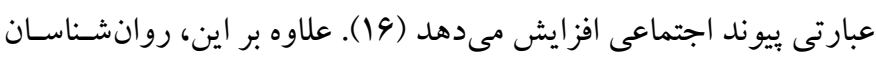

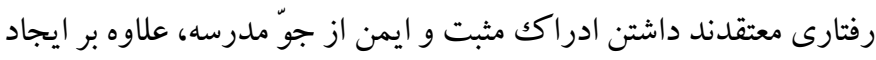

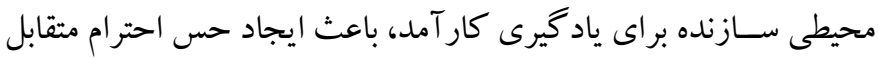

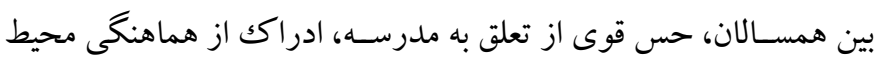

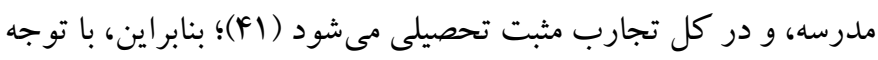
به ماهيت تقويت-محور مداخلات رفتارى يثوهش حاضر، مى توان جنين استدلال كرد كه ياد كيرى مهارتهاى تقويت خود و خودبازبينى در كنار

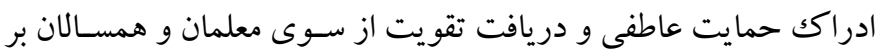
افزايش جايگاه اجتماعى و در نتيجه بهبودى بيوند با مدرسه دانش آموزان قلدر مؤثر بوده است. جنــدين محدوديت در مطالعه حاضــر وجود دارد كه بايد به آنها در

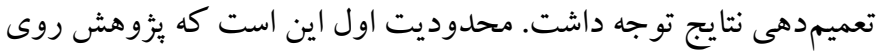
دانش آموزان بسـر مقطع ابتدايى اجرا شــد، لذا در تعميم يافتهها به سـاير

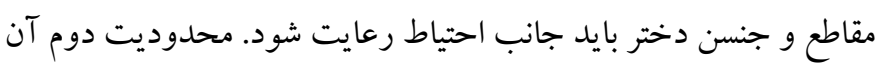

سـازو كارهاى رفتارى معلم و همسالان، ماهيت بويايى دارد و لزوم توجه

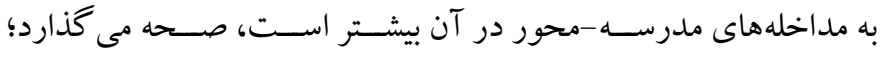

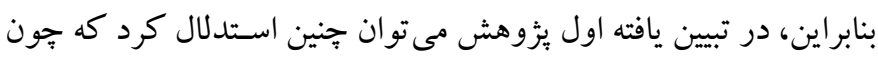

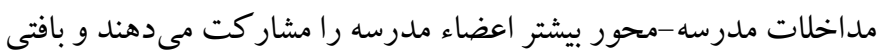

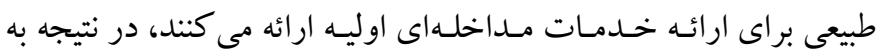
ماهيت بوياى قلدرى نزديكك مىشوند ( آ و الr).

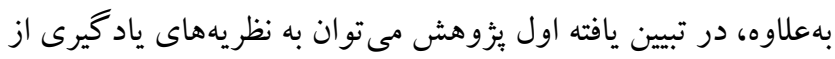

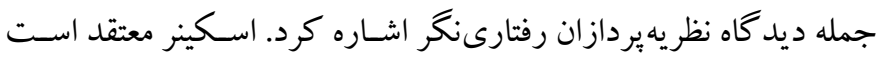

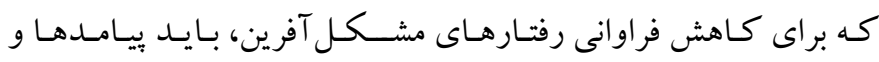

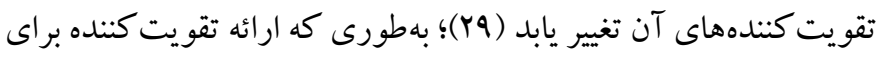

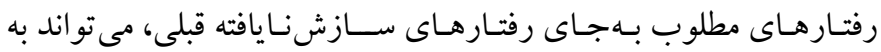

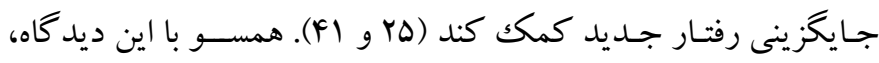

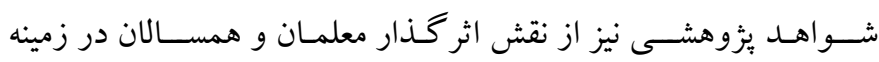
دست كارى منظم تقويت كنندهاى محيطى و در نتيجه كاهش رفتارهاى

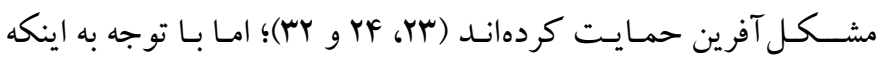
تـاريخجهـه تقويـت شــخصـى نيز بر بروز رفتـار نقش دارد، بنـابراين

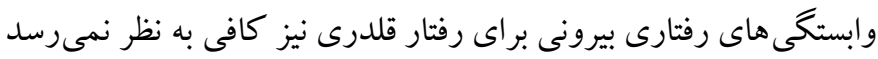

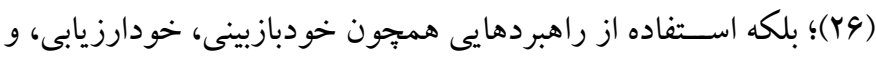

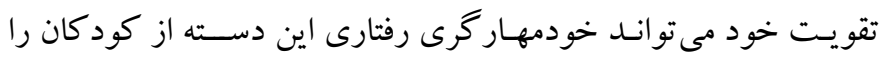
افزايش داده و رفتـار نـامطلوب آنها را كاهش دهند (Yو). نتيجه اين كه

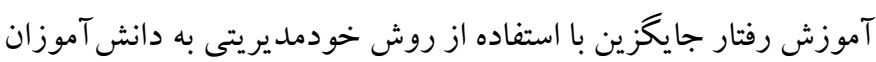

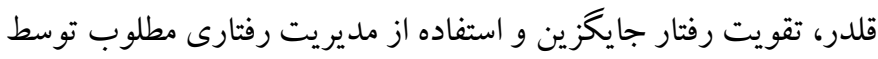

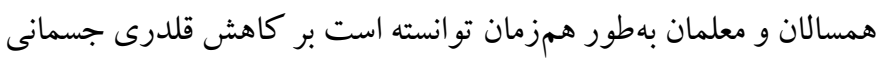
و زدوخورد كود كان اثر گذار باشد. يافته دوم ثيزوهش حاضـر نشان داد كه مداخله رفتارى مدرسه -محور

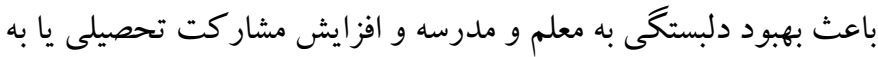

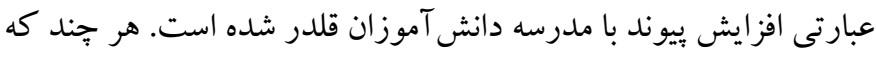

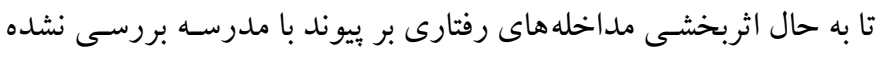

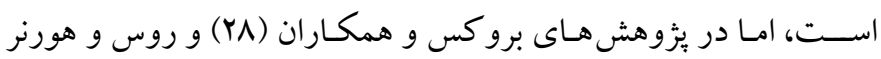

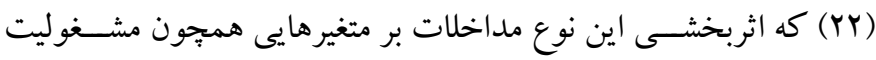
تحصيلى و احساس ايمنى در مدرسه بررسى شده است، افزايش معنادارى

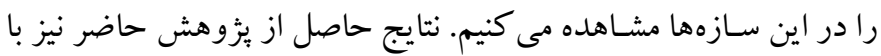


رفتـارهـاى نـامطلوب در مـدرســه كمكك كند. همٍجنين، اجر ای مداخله رفتارى مدرسـه-محور روى نقشهاى دركير در قلدرى بهمنظور افزايش

$$
\text { بيوند با مدرسه دانش آموزان بيشنهاد مىشود. }
$$

تشـكر و قدردانى: اين بثوهش بر گرفته از رساله دكتر ای خانم مينا محبى در

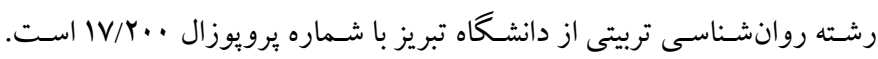

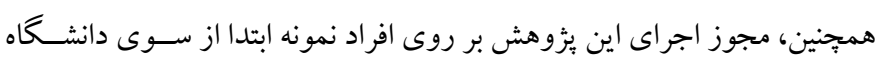
تبريز با شـماره نامه IV/YNA99، و سيس از سوى اداره آموزشويرورش ناحيه

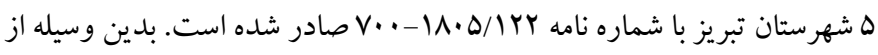

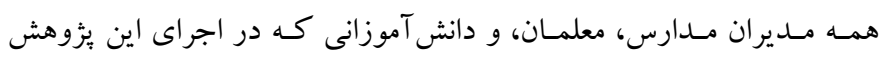
همكارى نمو دند، تشكر و قدردانى مىشود. تضــاد منافع: اين بثزوهش براى نويســد كان هيجِ گونه تضــاد منافعى نداشــه

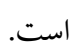

اسـت كه به طرفدار ان قلدر، آموزش مديريت رفتارى ارائه شــد اما هيج سـنجشى روى رفتار آنها انجام نشد؛ بنابراين به بثووهشخران آتى بيشنهاد

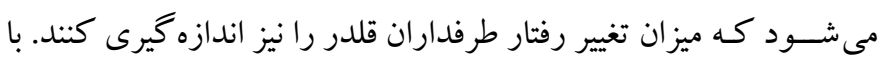
وجود اين محدوديت ها، نتايج يثوهش حاضسر بينش جديدى رادر زمينه نقش مــاخلـه رفتارى مدرســهـمحور بر كاهش قلدرى و بهبود بيوند با مدرســه كود كان فراهم مى كند و كاربردهايى براى عمل دارد. بهمنظور كاهش قلدرى و بهبود قابليت هاى تحصيلى دانش آموزان داراى رفتارهاى قلدرى، به روانشـاسـان مدرسـه بيشـنهاد مى شـود كه آموزش مديريت رفتار شخصى را به اين دسته از دانش آموزان در برنامه خويش قرار دهند. در كنار آن، آكاهى بسـيار ضـرورى اسـت. آموزش به همسـالان بهويزه آموزش مهارتهاى اجتماعى به طرفداران قلدر با هدف توانمندسـازى اين كروه در كاهش

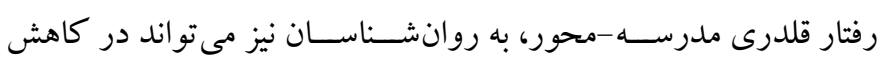




\section{References}

1. Olweus D. School bullying: development and some important challenges. Annu Rev Clin Psychol.2013; 9: 751-780. [Link]

2. Silva MAI, Pereira B, Mendonça D, Nunes B, Oliveira WA. The involvement of girls and boys with bullying: an analysis of gender differences. Int $\mathbf{J}$ Environ Res Public Health. 2013; 10(12): 6820-6831. [Link]

3. Salmivalli C, Lagerspetz K, Bjöorkqvist K, Österman $\mathrm{K}$, Kaukiainen A. Bullying as a group process: participant roles and their reactions to social status within the group. Aggress Behav. 1996; 22(1): 1-15. [Link]

4. Obermann M. Moral disengagement among bystanders to school bullying. J Sch Violence. 2011; 10(3): 239257. [Link]

5. Cho S, Lee JM. Explaining physical, verbal, and social bullying among bullies, victims of bullying, and bullyvictims: assessing the integrated approach between social control and lifestyles-routine activities theories. Child Youth Serv Rev. 2018; 91: 372-382. [Link]

6. Thornberg R, Jungert $T$. Bystander behavior in bullying situations: basic moral sensitivity, moral disengagement and defender self-efficacy. J Adolesc. 2013; 36(3): 475-483. [Link]

7. Ramya, SG, Kulkarni ML. Bullying among school children: prevalence and association with common symptoms in childhood. Indian J Pediatr. 2011; 78(3): 307-310. [Link]

8. AlBuhairan F, Abbas OA, Sayed DL, Badri M, Alshahri S, Vries N. The relationship of bullying and physical violence to mental health and academic performance: a cross-sectional study among adolescents in Kingdom of Saudi Arabia.Int J Pediatr Adolesc Med. 2017; 4(2): 61-65. [Link]

9. Elliott SN, Hwang Y-S, Wang J. Teachers' ratings of social skills and problem behaviors as concurrent predictors of students' bullying behavior. J Appl Dev Psychol. 2019; 60:119-126. [Link]

10. Chan HCO, Wong DSW. The overlap between school bullying perpetration and victimization: assessing the psychological, familial, and school factors of Chinese adolescents in Hong Kong. J Child Fam Stud. 2015; 24(11): 3224-3234. [Link]

11. Mohebbi M, Mirnasab M, Wiener J. Parental and school bonding in Iranian adolescent perpetrators and victims of bullying. Sch Psychol Int. 2016; 37(6): 583605. [Link]

12. Pabian S, Vandebosch H. Short-term longitudinal relationships between adolescents' (cyber) bullying perpetration and bonding to school and teachers. Int $\mathbf{J}$ Behav Dev. 2016; 40(2): 162-172. [Link]

13. Oelsner J, Lippold MA, Greenberg MT. Factors influencing the development of school bonding among middle school students. J Early Adolesc. 2011; 31(3): 463-487. [Link]

14. Moon B, Alarid LF. School bullying, low self-control and opportunity. J Interpers Violence. 2015; 30(5): 839-856. [Link]

15. Gottfredson MR, Hirschi T. A general theory of crime. Stanford University Press; 1990, pp: 1-316. [Link]

16. Hirschi T. Causes of delinquency. University of California Press, Berkeley; 1969, pp: 1-309.[Link]

17. Chan HCO, Chui WH. Social bonds and school bullying: a study of Macanese male adolescents on bullying perpetration and peer victimization. Child Youth Care Forum. 2013; 42(6): 599-616. [Link]

18. Cuffy SA. Principals' perceptions of the bully busters program in combating cyber bullying in elementary schools [Doctoral Thesis]. [Washington, USA]: Education Faculty, Walden University; 2015, pp: 1129. [Link]

19. Limber SP, Olweus D, Wang W, Masiello M, Breivik $\mathrm{K}$. Evaluation of the Olweus bullying prevention program: a large scale study of US students in grades 3-11. J Sch Psychol. 2018; 69: 56-72.[Link]

20. Nocentini A, Menesini E. KiVa anti-bullying program in Italy: evidence of effectiveness in a randomized control trial. Prev Sci. 2016; 17(8): 1012-1023. [Link]

21. Kärnä A, Voeten M, Little TD, Poskiparta E, Alanen E, Salmivalli C. Going to scale: a nonrandomized nationwide trial of the KiVa antibullying program for grades 1-9. J Consult Clin Psychol. 2011; 79(6): 796805. [Link]

22. Ross SW, Horner RH. Bully prevention in positive behavior support: preliminary evaluation of thirdfourth-, and fifth-grade attitudes toward bullying. J Emot Behav Disord. 2014; 22(4): 225-236. [Link]

23. Lynch $D$, Keenan $M$. The good behavior game: maintenance effects. Int J Educ Res. 2018; 87: 91-99. [Link]

24. Wallace MD, Iwata BA, Hanley GP, Thompson RH, Roscoe EM. Noncontingent reinforcement: a further examination of schedule effects during treatment. J Appl Behav Anal. 2012; 45(4): 709-719. [Link]

25. Heron TE, Heward WL, Cooper JO. Applied behavior analysis. Pearson Education; 2013, pp: 1-800. [Link]

26. Cole CL, Bambara LM. Issues surrounding the use of self-management interventions in the schools. School Psych Rev. 1992; 21(2): 193-201. [Link] 
27. Kern L, Ringdahl JE, Hilt A, Sterling-Turner HE. Linking self-management procedures to functional analysis results. Behavioral Disorders. 2001; 26(3): 214-226. [Link]

28. Brooks A, Todd AW, Tofflemoyer S, Horner RH. Use of functional assessment and a self-management system to increase academic engagement and work completion. J Posit Behav Interv. 2003; 5(3): 144152. [Link]

29. Skinner BF. The behavior of organisms: an experimental analysis. Oxford, England: AppletonCentury; 1938, pp: 1-457. [Link]

30. Hansen BD, Wills HP, Kamps DM, Greenwood CR. The effects of function-based self-management interventions on student behavior. J Emot Behav Disord. 2014; 22(3): 149-159. [Link]

31. Allen KP. Classroom management, bullying, and teacher practices. Professional Educator. 2010; 34(1): 1-15. [Link]

32. Broussard C, Northup J. The use of functional analysis to develop peer interventions for disruptive classroom behavior. Sch Psychol Q. 1997; 12(1): 6576. [Link]

33. Cohen L, Manion L, Morrison K. Research methods in education. 7th Edition. London: Routledge; 2011, pp: 1-762. [Link]

34. Pekarik EG, Prinz RJ, Liebert DE, Weintraub S, Neale JM. The pupil evaluation inventory. J Abnorm Child Psychol. 1976; 4(1): 83-97. [Link]

35. Pouwels JL, Lansu TA, Cillessen AH. Participant roles of bullying in adolescence: status characteristics, social behavior, and assignment criteria. Aggress Behav. 2016; 42(3):239-253. [Link]
36. Werthamer-Larsson L, Kellam S, Wheeler L. Effect of first-grade classroom environment on shy behavior, aggressive behavior, and concentration problems. Am J Community Psychol. 1991; 19(4): 585-602. [Link]

37. Goossens FA, Olthof T, Dekker PH. New participant role scales: comparison between various criteria for assigning roles and indications for their validity. Aggress Behav. 2006; 32(4): 343-357. [Link]

38. Espelage DL, Holt MK. Bullying and victimization during early adolescence: peer influences and psychosocial correlates. Journal of Emotional Abuse. 2001; 2(2-3): 123-142. [Link]

39. ChalmehR. Psychometrics properties of the ilinois bullying scale (IBS) in Iranian students: validity, reliability and factor structure. Journal of Psychological Models and Methods. 2014; 3(11): 3952. [Persian]. [Link]

40. Cernkovich SA, Giordano PC. School bonding, race and delinquency.Criminology. 1992; 30(2): 261-291. [Link]

41. Alberto P, Troutman AC. Applied behavior analysis for teachers. (8th ed.). Upper Saddle River, NJ: Pearson; 2009, pp: 1-480. [Link]

42. Parsonson BS. Evidence-based classroom behavior management strategies. Kairaranga. 2012; 13(1): 1623. [Link]

43. Caravita SCS, Blasio PD, Salmivalli C. Unique and interactive effects of empathy and social status on involvement in bullying. Soc Dev. 2009; 18(1): 140163. [Link] 